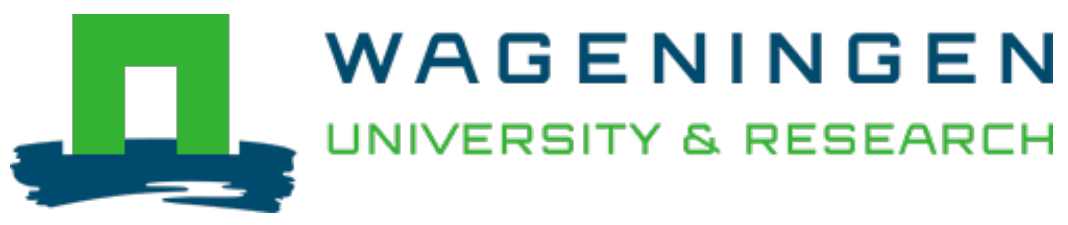

\title{
Techniques for Enzyme Purification
}

Biocatalysis for Practitioners

Westphal, Adrie H.; Berkel, Willem J.H.

https://doi.org/10.1002/9783527824465.ch1

This publication is made publicly available in the institutional repository of Wageningen University and Research, under the terms of article $25 \mathrm{fa}$ of the Dutch Copyright Act, also known as the Amendment Taverne. This has been done with explicit consent by the author.

Article $25 \mathrm{fa}$ states that the author of a short scientific work funded either wholly or partially by Dutch public funds is entitled to make that work publicly available for no consideration following a reasonable period of time after the work was first published, provided that clear reference is made to the source of the first publication of the work.

This publication is distributed under The Association of Universities in the Netherlands (VSNU) 'Article $25 \mathrm{fa}$ implementation' project. In this project research outputs of researchers employed by Dutch Universities that comply with the legal requirements of Article $25 \mathrm{fa}$ of the Dutch Copyright Act are distributed online and free of cost or other barriers in institutional repositories. Research outputs are distributed six months after their first online publication in the original published version and with proper attribution to the source of the original publication.

You are permitted to download and use the publication for personal purposes. All rights remain with the author(s) and / or copyright owner(s) of this work. Any use of the publication or parts of it other than authorised under article $25 \mathrm{fa}$ of the Dutch Copyright act is prohibited. Wageningen University \& Research and the author(s) of this publication shall not be held responsible or liable for any damages resulting from your (re)use of this publication.

For questions regarding the public availability of this publication please contact openscience.library@wur.nl 


\section{Biocatalysis for Practitioners}

\section{Techniques, Reactions and Applications}

de Gonzalo, Gonzalo / Lavandera, Iván (Editor)

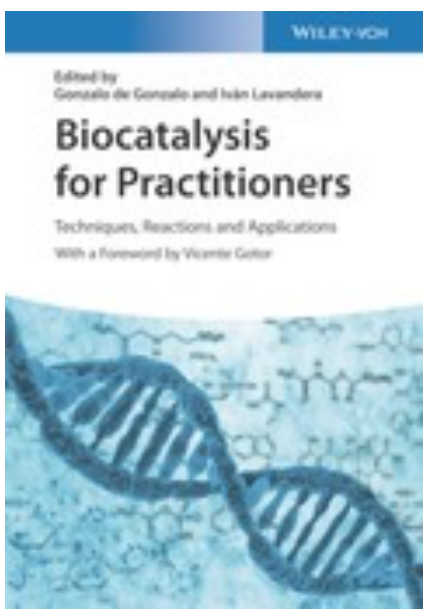

1. Edition April 2021

528 Pages, Softcover

49 Pictures (23 Colored Figures)

31 tables

Practical Approach Book

ISBN: 978-3-527-34683-7

Wiley-VCH, Weinheim

\section{Short Description}

This books presents a overview with a clear focus on practical aspects on biocatalysis. Reliable experimental information, useful purification methods and tips and tricks for the use of enzymes are included. A must-have for everyone who works or is going to work in this field.

Section 1. Enzyme techniques

Techniques for Enzyme Purification

Enzyme modification

Immobilization techniques for the preparation of supported biocatalysts Making better biocatalysts through protein immobilization

Compartmentalization in biocatalysis

Section 2. Enzymes handling and applications

Promiscuous activity of hydrolases

Enzymes applied to the synthesis of amines

Applications of Oxidoreductases in Synthesis: a Roadmap to Access Value-added Products

Glycosyltransferase cascades made fit for the biocatalytic production of natural product glycosides

Section 3. Ways to improve enzymatic transformations

Application of Non-aqueous Media in Biocatalysis

Non-conventional cofactor regeneration systems

Biocatalysis under Continuous Flow Conditions

Section 4. Recent trends in enzyme-catalyzed reactions

PhotoBiocatalysis

Practical multienzymatic transformations. Combining enzymes for the one-pot synthesis of organic molecules in a straightforward manner

Chemoenzymatic sequential protocols

Section 5. Industrial Biocatalysis

Industrial processes using biocatalysts

Enzymatic commercial sources 


\section{Techniques for Enzyme Purification}

Adrie H. Westphal ${ }^{1}$ and Willem J. H. van Berkel ${ }^{1,2}$

\footnotetext{
${ }^{1}$ Wageningen University \& Research, Laboratory of Biochemistry, Stippeneng 4, 6708WE Wageningen, The Netherlands

${ }^{2}$ Wageningen University \& Research, Laboratory of Food Chemistry, Bornse Weilanden 9, 6708WG, Wageningen,

The Netherlands
}

\subsection{Introduction}

Biocatalysis is the chemical process through which enzymes or other biological catalysts perform reactions between organic components. Biocatalysis gives an added dimension to synthetic chemistry and offers great opportunities to prepare industrial useful chiral compounds $[1,2]$. Depending on the goal of the chemical conversion and the costs involved, biocatalyst-driven reactions are performed using whole cell systems or isolated enzymes, either in free or immobilized form [3-5].

Initially, industrial applications utilizing isolated enzymes were mainly developed with amylases, lipases, and proteases [6-8]. These hydrolytic enzymes were usually applied in a partially purified form, also because crude enzyme preparations are often more stable than the purified ones. However, for obtaining highly pure products, especially in the pharmaceutical industry, the purity of the enzyme preparation can be a critical factor.

Many enzyme purification methods have been developed over the years. Traditional purification procedures make use of the physicochemical properties of the enzyme of interest. These procedures were developed during the twentieth century for elucidating enzyme mechanisms and solving protein three-dimensional structures but also appeared to be valuable for the preparation of highly pure biocatalysts. Yet, progress in the preparation of biocatalysts has been given the biggest boost by the amazing developments in recombinant DNA technology and the accompanying revolutionary changes in enzyme production, enzyme purification, and enzyme engineering [9].

Here, we describe our experiences with the contemporary techniques for enzyme purification. For more information about the practical issues of enzyme purification, the reader is referred to the "Guide to Protein Purification" in Methods in Enzymology 463 [10]. 


\subsection{Traditional Enzyme Purification}

Before summarizing the traditional enzyme purification methods, it is important to note that the purification of enzymes is made easier by the fact that they are such specific catalysts. This enables the determination of the amount of a given enzyme in units (where 1 unit [U] of enzyme activity is defined as the amount of enzyme that catalyzes the conversion of $1 \mu \mathrm{mol}$ substrate per minute) and its specific activity (in $\mathrm{Umg}^{-1}$ ) in crude extracts and after each purification step. The specific activity is a good indication of the purity and quality of the enzyme preparation, especially if the specific activity of the pure enzyme under defined conditions is known. During enzyme purification, the improvement in specific activity and the yield of the enzyme after each purification step can be summarized in a purification scheme. The purification factor (specific activity obtained after a purification step divided by that of the starting material) provides an insight into the "efficiency" of each step. If a pure enzyme is obtained, it also indicates the relative amount of that enzyme present in the starting material. A theoretical example of a purification scheme, comprising three purification steps, is shown in Table 1.1.

Enzymes that are used for biocatalysis are typically purified from microbial cells or from culture media after or during growth of microorganisms (in case of excreted proteins). The enzyme purification generally starts with a cleared cell extract in which the enzyme is present in a soluble form. If the enzyme to be purified is excreted into the culture medium, it is usually sufficient to remove the cells from the medium by centrifugation (for small-scale purifications) or by filtration (for large-scale industrial purifications). In the case of an intracellular enzyme, cells should be broken first to release the protein into solution. Depending on the type of cells, different techniques are employed. The microbial cells are first harvested from the culture medium by centrifugation and resuspended in a small amount of buffer. The cells can be broken using a variety of techniques, e.g. by treatment with enzymes that digest cell walls (e.g. lysozyme), followed by osmotic shock, by using lysis buffers containing detergents, by exposure to ultrasound using sonicators, by pushing cells under high pressure through a small orifice using a pressure cell system, or by grinding frozen cells in liquid nitrogen. Extracts thus obtained are cleared from unbroken cells and large, insoluble particles by centrifugation or filtration. To prevent enzyme inactivation during these treatments, and also in the following purification steps, the temperature

Table 1.1 Imaginary traditional enzyme purification scheme.

\begin{tabular}{lcccccc}
\hline Step & Volume $(\mathbf{m l})$ & $\begin{array}{c}\text { Activity } \\
(\mathbf{U})\end{array}$ & $\begin{array}{c}\text { Protein } \\
(\mathbf{m g})\end{array}$ & $\begin{array}{c}\text { Specific activity } \\
\left(\mathbf{U ~ m g ~}^{-1}\right)\end{array}$ & $\begin{array}{c}\text { Yield } \\
(\%)\end{array}$ & Purification factor \\
\hline $\mathrm{CE}$ & 500 & 3000 & 15000 & 0.2 & 100 & 1.0 \\
$\mathrm{AS}$ & 100 & 2400 & 4000 & 0.6 & 80 & 3.0 \\
$\mathrm{IEC}$ & 45 & 1440 & 500 & 2.9 & 48 & 14.5 \\
$\mathrm{GF}$ & 50 & 1000 & 125 & 8.0 & 33 & 40.0 \\
\hline
\end{tabular}

Steps: CE, cell extract; AS, ammonium sulfate fractionation; IEC, ion exchange chromatography; GF, gel filtration. 
of the enzyme solution is usually kept around $4{ }^{\circ} \mathrm{C}$. Proteolytic degradation of the enzyme to be purified can be precluded by adding a protease inhibitor cocktail during breaking of the cells.

Once a cell-free extract has been obtained, several methods can be employed for further purification of the desired enzyme. These separation methods can be roughly divided into the following categories: (i) selective precipitation, (ii) separation based on charge, (iii) separation based on molecular size, (iv) separation based on bio-affinity, and (v) separation based on adsorption principles. Except for the first category, all these methods generally make use of column chromatography, with column sizes depending on the scale of the sample volumes and protein concentrations.

The strategy applied during enzyme purification is such that separation methods belonging to different categories are carried out in a logical order until the goal is reached. A good purification results in the recovery of most of the enzyme activity (i.e. a high yield) and in removal of many "contaminating" proteins and other types of (bio)molecules (i.e. a strong increase in specific activity). An often-experienced phenomenon during purification is the inactivation and/or aggregation of the enzyme (Figure 1.1). Because of increased enzyme concentration in the final steps of purification, aggregation can occur. If proteases are still present, the enzyme becomes more and more the only target for the protease, which can lead to proteolysis. In addition, wrong physical conditions $(\mathrm{pH}$, temperature, and ionic strength) can lead to (partly) unfolding, followed by aggregation and/or proteolysis. Changing the type of buffer, $\mathrm{pH}$, and/or ionic strength and the addition of protecting agents may alleviate these processes.

The purity of the final enzyme preparation can be tested in several ways. The most common methods used are sodium dodecyl sulfate polyacrylamide gel electrophoresis (SDS-PAGE) (Figure 1.2), analytical gel filtration, and mass spectrometry [11].
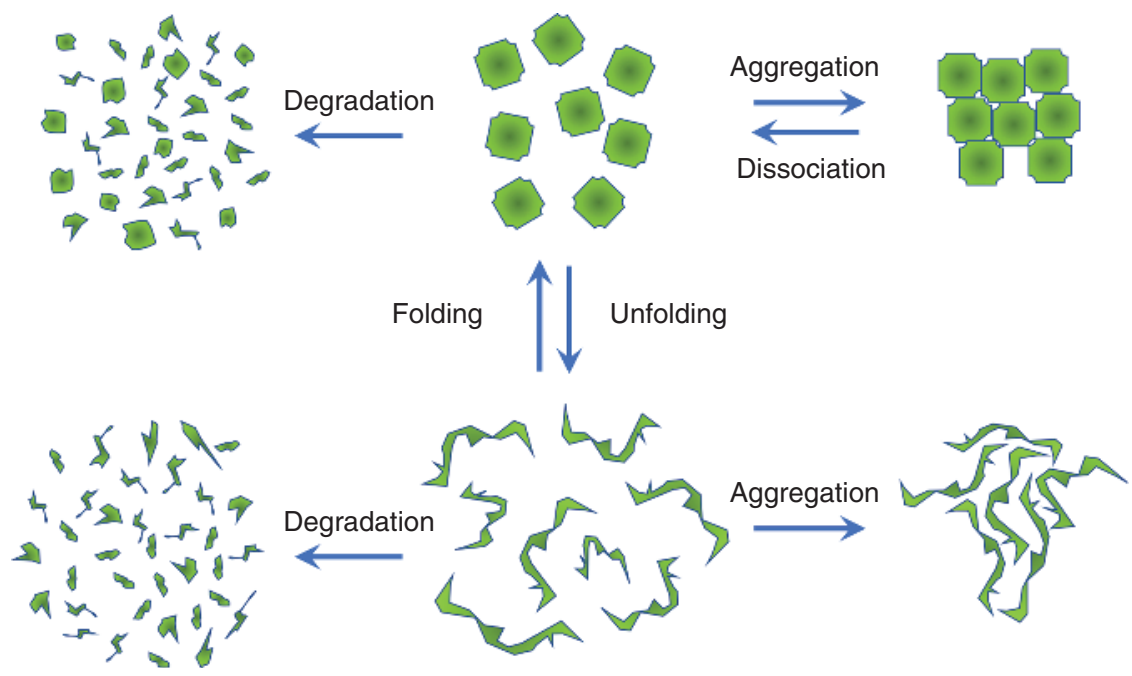

Figure 1.1 Enzyme aggregation and proteolytic degradation processes. 


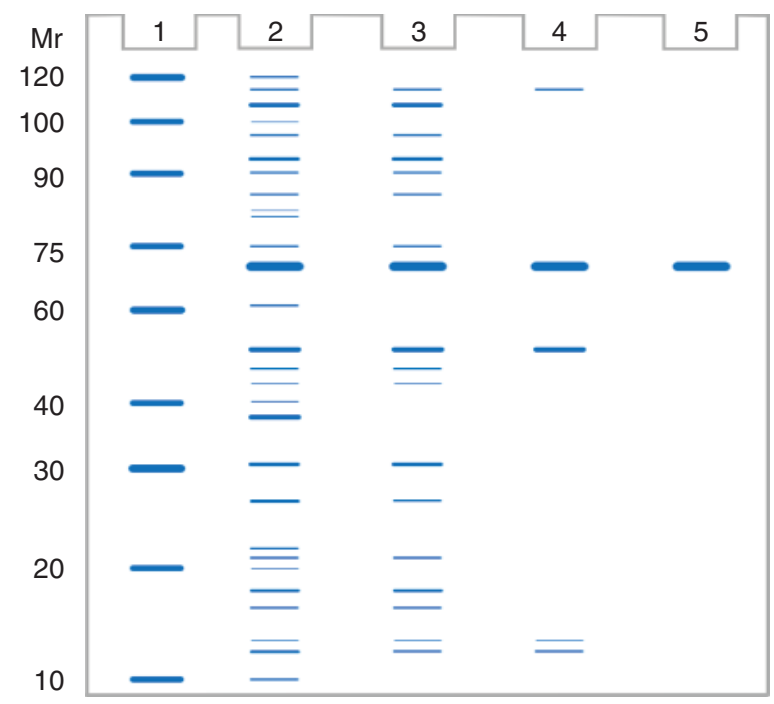

Figure 1.2 Example of an SDS-PAGE gel. (1) Molecular mass markers, (2) cell extract, (3) sample after ammonium sulfate fractionation, (4) sample after ion exchange chromatography, and (5) sample after gel filtration. Mr., relative molecular mass (kDa).

Traditional enzyme purification procedures many times start with an ammonium sulfate fractionation. This type of fractionation makes use of the fact that individual proteins precipitate at different concentration ranges of ammonium sulfate [12].

To make an estimation of the fractionation range, a small-scale pilot experiment can be performed. For such an experiment, different amounts of ammonium sulfate (from $0 \%$ to 90\% saturation) are added to small samples of cell extract (usually, $1 \mathrm{ml}$ ). After dissolving the ammonium sulfate and removal of the formed protein precipitates by centrifugation, enzyme activity of the supernatants is measured (Figure 1.3). Such an analytical pilot experiment tells us at which saturation value the enzyme starts to precipitate (in our pilot, around 30\%) and at which degree of saturation precipitation of the enzyme is more or less complete (in our pilot, around 65\%). Once these values have been determined, the bulk of the cell extract is fractionated using these percentages and the precipitate obtained after the second addition of ammonium sulfate is used for further purification. If desired, removal of ammonium sulfate can be accomplished by dialysis, ultrafiltration, or gel filtration (e.g. with desalting columns).

Ammonium sulfate fractionation has been used in our group for the purification of several oxidoreductases. For the purification of vanillyl alcohol oxidase from Penicillium simplicissimum [13], the ammonium sulfate fractionation of the cell extract from $30 \%$ to $60 \%$ saturation gave a yield of $85 \%$. Although few protein impurities were removed (as judged from SDS-PAGE and from the rather low purification factor of 1.2), this step appeared to be advantageous for the subsequent purification using a Phenyl Sepharose column, especially because ammonium sulfate removal could be omitted before this hydrophobic interaction chromatography (HIC) step. A similar experience was made with the purification of catalase peroxidase from P. simplicissimum [14] and 4-hydroxybenzoate 3-hydroxylase from 


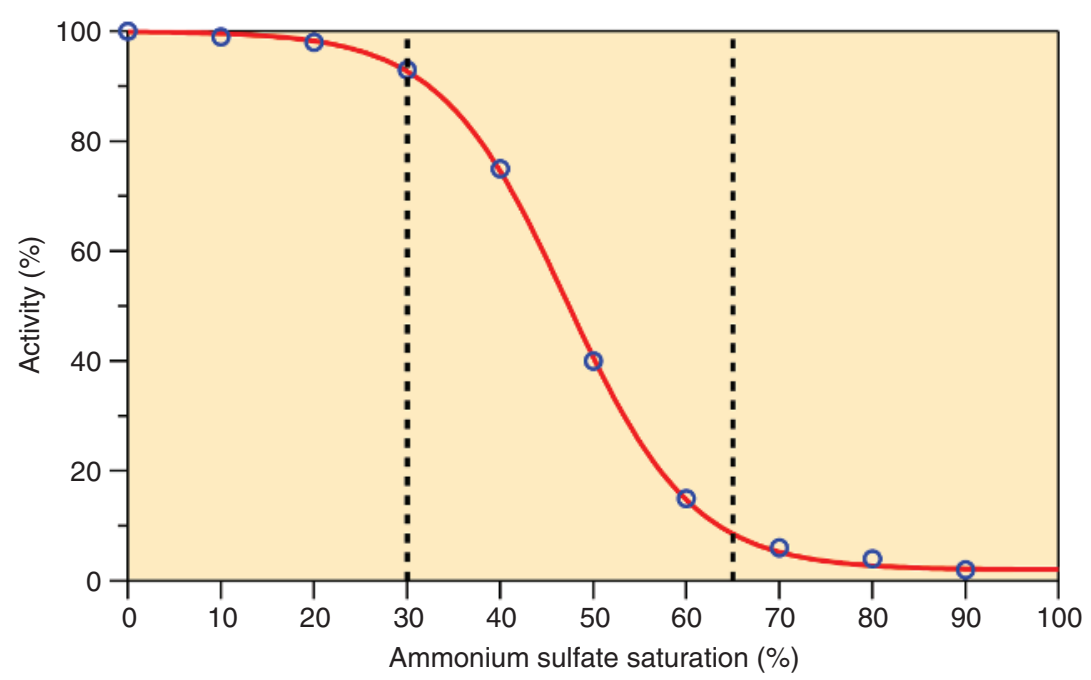

Figure 1.3 Ammonium sulfate fractionation. In this example, a pilot experiment is performed on small cell extract samples. Next, $30 \%$ saturation is used on the total extract sample and the precipitates formed are removed by centrifugation. Then, the supernatant is brought to $65 \%$ saturation and the precipitate, which contains most of the enzyme activity, is collected by centrifugation.

Rhodococcus opacus 557 [15]. With hydroquinone dioxygenase from Pseudomonas fluorescens ACB [16], the cell-free extract was adjusted to $25 \%$ ammonium sulfate saturation before loading onto a Phenyl Sepharose column. Ammonium sulfate can also be used to concentrate the solution during enzyme purification. In the case of 4-hydroxybenzoate 1-hydroxylase from Candida parapsilosis [17], the enzyme fraction obtained after Q-Sepharose ion exchange chromatography (IEC) was adjusted to 70\% saturation with pulverized ammonium sulfate and the resulting precipitate, collected by centrifugation, was dissolved in a small amount of buffer.

\subsubsection{Ion Exchange Chromatography}

IEC is one of the most widely used methods for enzyme purification. It separates protein molecules according to their differences in charge [18]. The stationary phase (matrix) in IEC carries charged functional groups fixed by chemical bonds. The fixed groups are associated with exchangeable counterions. In anion exchange chromatography, the fixed groups have positive charges and in cation exchange chromatography, these groups are negatively charged. As a rule of thumb, proteins bind to an anion exchanger at $\mathrm{pH}$ values above their isoelectric point (pI) and to a cation exchanger at $\mathrm{pH}$ values below the pI. Protein IEC usually involves the following steps:

(1) Equilibration: The ion exchange resin is equilibrated with a low-salt buffer that allows binding of the enzyme of interest.

(2) Sample application and adsorption: Protein molecules with a proper charge displace counterions and bind reversibly to the matrix. The ionic strength of the buffer in which 
the protein sample is loaded should be low, as a high concentration of salt usually prevents binding. Any volume of sample can be applied as long as the total amount of protein does not exceed the binding capacity of the matrix. Yet, a large sample volume having a low concentration of precipitates may eventually clog the column. Proteins in the sample not bound by the matrix can be washed from the column using a loading buffer. To follow elution of nonbinding proteins, the absorbance of the column effluent can be monitored at 214 or $280 \mathrm{~nm}$ in the case of a low amount of protein in the sample or at $305 \mathrm{~nm}$ in the case of high protein concentrations.

(3) Desorption of bound proteins: A stepwise increase of salt concentration or, in most cases, a gradual increase of the salt concentration (gradient) of the elution buffer is used. Again, the elution of proteins can be monitored by measuring the absorbance of the column effluent at 214 or $280 \mathrm{~nm}$ and, in addition, at a visible wavelength in the case of colored proteins. Elution with a shallow continuous gradient has the advantage that proteins with small differences in $\mathrm{pI}$ values are better separated and elute from the column in sharp, symmetrical peaks. For some enzymes, activity may be lost at high salt concentrations (e.g. because of dissociation of subunits). In that case, an elution can be attempted using a $\mathrm{pH}$ change step or a $\mathrm{pH}$ change gradient.

(4) Cleaning of the column: Proteins and other substances that are bound very strongly to the column are removed. This is usually done by "cleaning-in-place," using $2 \mathrm{M} \mathrm{NaCl}$ or $0.5 \mathrm{MNaOH}$ solutions, followed by washing with water/buffer and $20 \%$ ethanol for storage.

IEC is a very powerful (preparative) purification method because (i) the high binding capacity of ion exchange columns allows elution of proteins in a very concentrated form and (ii) a proper choice of elution conditions results in separation of the bound proteins at high resolution.

For many years, IEC was included in almost every enzyme purification procedure, both on lab scale and at industrial level. Although this picture has changed after the introduction of the recombinant DNA technology providing the use of affinity tags, IEC remains a superior technology for enzyme purification because of its large resolving power and high recovery of enzyme activity.

In our experience, the IEC technique appeared to be crucial for the purification of a wide range of oxidoreductases, including monooxygenases, oxidases, dioxygenases, peroxidases, reductases, and dehydrogenases (Table 1.2).

A specific application of IEC involved the separation of native and oxidized forms of the flavoenzyme 4-hydroxybenzoate 3-hydroxylase from P. fluorescens [21]. The sensitivity of this dimeric enzyme to air oxidation resulted in different isoforms, which could be separated on a preparative scale with a DEAE-Sepharose column (Figure 1.4). Further analysis with an analytical Mono-Q column and isoelectric focusing experiments revealed the 10 different isoforms possible, assigned to combinations of the sulfhydryl, sulfenic acid, sulfinic acid, and sulfonic acid state of the surface-accessible Cys116 of each subunit. Mixing a native enzyme and a fully oxidized enzyme resulted in extremely slow formation of hybrid dimers with one native and one fully oxidized subunit, pointing to the high stability of the enzyme dimer. 
Table 1.2 Ion exchange chromatography of oxidoreductases.

\begin{tabular}{llc}
\hline Enzyme family & Enzyme & References \\
\hline Flavoprotein hydroxylases & 4-Hydroxybenzoate 3-hydroxylase & {$[14,19-22]$} \\
& 4-Hydroxybenzoate 1-hydroxylase & {$[16]$} \\
& 3-Hydroxyphenylacetate 6-hydroxylase & {$[23]$} \\
& Hydroquinone hydroxylase & {$[24]$} \\
& Phenol hydroxylase (PheA1) & {$[25]$} \\
& 3-Hydroxybenzoate 6-hydroxylase & {$[26]$} \\
Baeyer-Villiger monooxygenases & 4-Hydroxyacetophenone monooxygenase & {$[27]$} \\
Copper-dependent monooxygenases & Polyphenol oxidase (tyrosinase) & {$[28]$} \\
& Lytic polysaccharide monooxygenase & {$[29]$} \\
Flavoprotein oxidases & Vanillyl alcohol oxidase & {$[13]$} \\
Multicopper oxidases & Eugenol oxidase & {$[30]$} \\
Non-heme iron dioxygenases & Laccase-like multicopper oxidase & {$[31,32]$} \\
Heme-dependent peroxidases & Hydroquinone dioxygenase & {$[33]$} \\
& Catalase peroxidase & {$[12]$} \\
Reductases & Cationic peroxidase & {$[34]$} \\
Nicotinamide-dependent dehydrogenases & Alcohol dehydrogenase & {$[25,35]$} \\
& Carveol dehydrogenase & {$[36]$} \\
\hline Flavin-dependent dehydrogenases & Galactonolactone dehydrogenase & {$[38,39]$} \\
& Proline dehydrogenase & {$[40]$} \\
\hline
\end{tabular}

Most of the listed enzymes were purified with several traditional separation methods described in this review. See references for details.

\subsubsection{Gel Filtration}

In gel filtration, also referred to as molecular sieve or size exclusion chromatography (SEC), sample molecules do not bind to the column but are fractionated based on their relative size and shape [41]. The liquid phase in such a column (total volume, $V_{t}$ ) has two measurable volumes: external or "void" volume, consisting of the liquid between the beads $\left(V_{0}\right)$, and the internal volume $\left(V_{i}\right)$, constituted by the liquid within the pores of the beads. Molecules being too large to enter the pores cannot equilibrate with $V_{i}$ and therefore emerge first from the column, while small molecules can equilibrate with $V_{i}$ and therefore elute later.

The most important parameters in SEC are (i) the diameter of the pores allowing access to the internal volume of the beads, (ii) the total internal volume of the beads, (iii) the hydrodynamic diameter of the sample molecules, (iv) the flow rate of the liquid phase, and (v) the operation temperature and viscosity of the buffer used. 


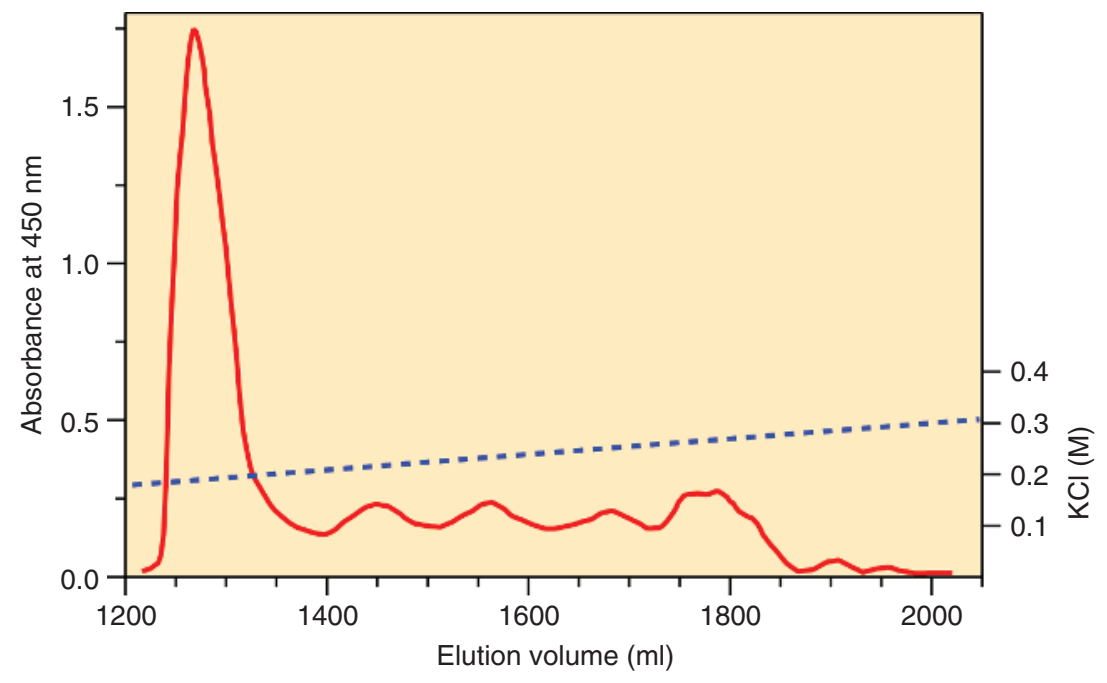

Figure 1.4 IEC of isoforms of highly pure 4-hydroxybenzoate 3-hydroxylase (PHBH) from Pseudomonas fluorescens. Preparative separation on DEAE-Sepharose CL-6B (650 mg protein) using a gradient elution. The small peaks after the main peak contain differently oxidized forms of PHBH. Source: Modified from van Berkel and Müller [21].

Elution volumes of fractionated molecules should be intermediate between $V_{0}$ and $V_{t}$. The elution volume ( $V_{e}$, Figure 1.5a) relates to the accessibility of the molecule to the pores of the beads: $V_{e}=V_{0}+K_{\mathrm{AV}} * V_{i}$ (where the partition coefficient $\left.K_{\mathrm{AV}}=\left(V_{e}-V_{0}\right) /\left(V_{t}-V_{0}\right)\right)$. A semi-logarithmic plot illustrating the relation between $K_{\mathrm{AV}}$ and protein molecular weight $\left(M_{r}\right)$ is given in Figure 1.5b. The separation of proteins according to $M_{r}$ is greatest in the central, linear region of the sigmoidal curve, spanning $K_{\mathrm{AV}}$ values between 0.2 and 0.8 . This span is described as the fractionation range of a size exclusion matrix. A steep slope of the sigmoidal curve indicates a large resolving power of a matrix for a certain molecular weight range.

Next to being a suitable purification step [28, 29, 35, 40, 42], SEC is extremely useful to get information about the molecular weight of the native protein and its possible subunit composition [43]. By using this technique, we established that 4-hydroxybenzoate 3-hydroxylase from $P$. fluorescens is a homodimer, both in its holo and apo form [19, 44]. For lipoamide dehydrogenase from $P$. fluorescens, we experienced that nicotinamide adenine dinucleotide reduced (NADH) binding strongly stimulates flavin adenine dinucleotide (FAD)-induced dimerization [45].

For vanillyl alcohol oxidase from $P$. simplicissimum, we found that the holoenzyme favors the octameric state [13, 46], whereas the apoenzyme [47] mainly exists as a dimeric species. The octamer-dimer equilibrium of the holoenzyme varied with the ionic strength of the buffer solution, with kosmotropic salts stimulating the octameric state [48, 49]. More recently, it was established that a single loop at the protein surface is essential for the octamerization of vanillyl alcohol oxidase [30].

For hydroquinone dioxygenase from $P$. fluorescens ACB, we obtained strong indications from gel filtration that this non-heme, iron-dependent enzyme is an $\alpha 2 \beta 2$ 


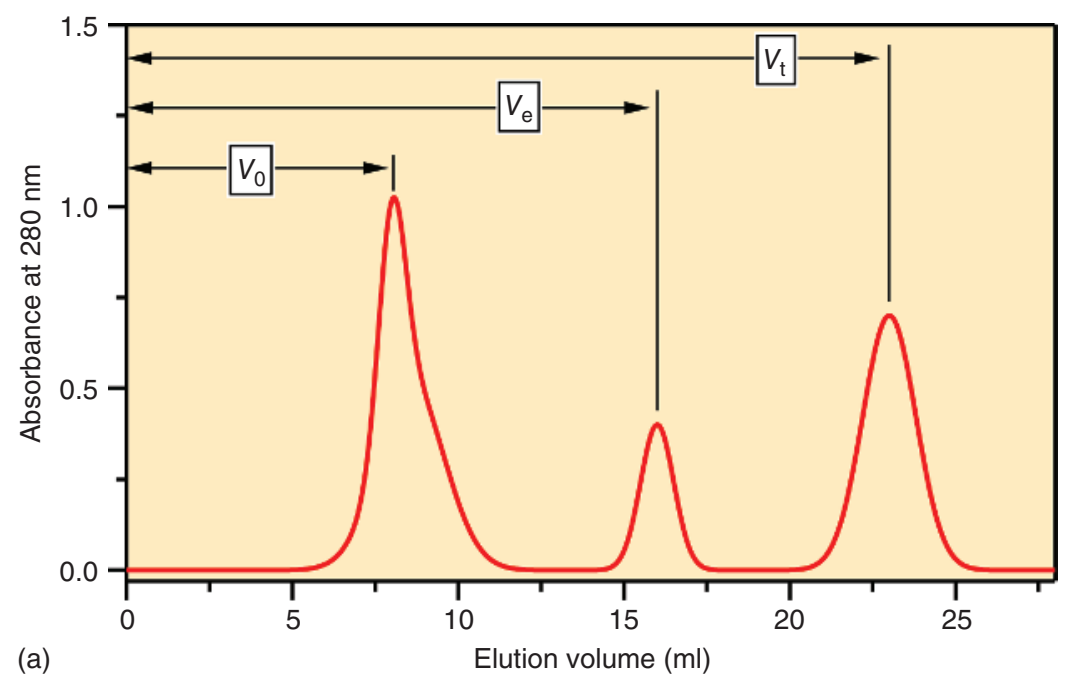

(a)

Elution volume $(\mathrm{ml})$

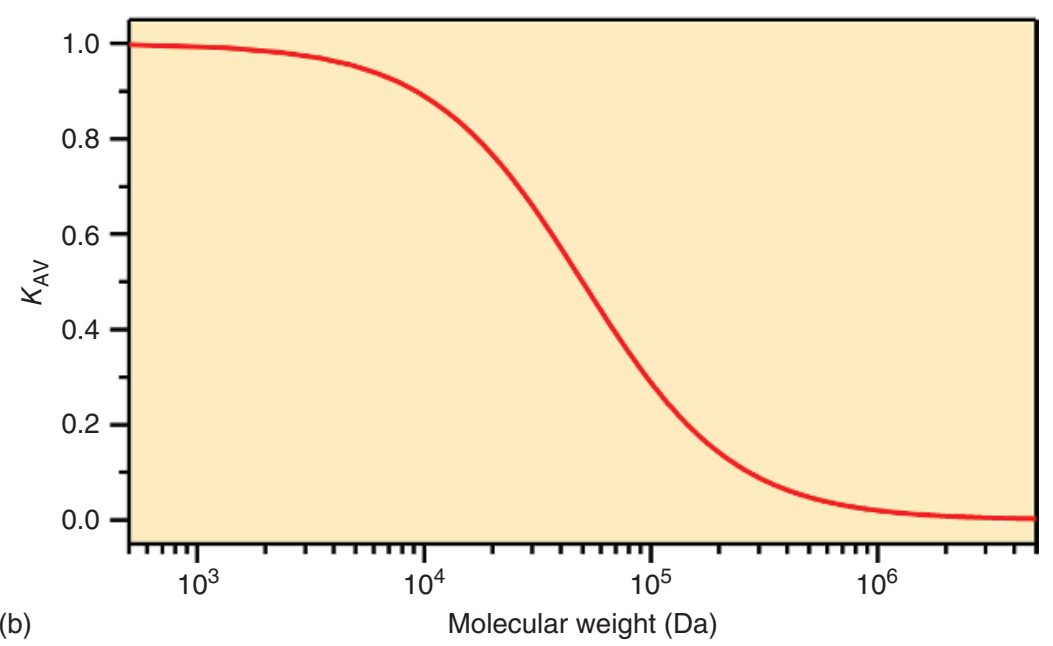

Figure 1.5 Gel filtration. (a) Elution profile and (b) $K_{\mathrm{AV}}$ vs $\log M_{r}$ plot.

heterotetramer [33]. With proline dehydrogenase from Thermus thermophilus, we showed that the native enzyme is a homotetramer $[40,50]$ and that dimerization of the protein subunits strongly increases the enzyme thermostability [51]. For 3-hydroxybenzoate 6-hydroxylase from Rhodococcus jostii RHA1, we obtained evidence that the monomermonomer contact of the dimer is stabilized by the binding of a phosphatidylinositol ligand [20].

\subsubsection{Bio-affinity Chromatography}

Bio-affinity chromatography is one of the most powerful procedures in protein purification. This method has a very high selectivity as it utilizes the specific, reversible 
interactions between biomolecules [52]. Classic enzyme affinity chromatography mainly focused on methods that made use of the specific interactions of enzymes with ligands, such as substrates, coenzymes, inhibitors, and activators. Through immobilization of such ligands on suitable matrices, enzymes can be selectively bound to these resins (see example of old yellow enzyme given below). Preferably, the dissociation constant $\left(K_{d}\right)$ of an enzyme-immobilized ligand complex should not change substantially compared to that of the enzyme-ligand complex free in solution. The dissociation constant range of the complex may vary from micromolar (enzyme-coenzyme complexes) to nanomolar (enzyme inhibitor complexes).

In bio-affinity chromatography, proteins to be purified are brought onto a column containing the immobilized ligand. After application of sample to the column, nonbinding proteins are washed out. Protein(s) that are retained on the column by their specific interaction with the ligand are removed by changing the elution conditions. The most specific way is by using a soluble ligand, which is competitive for the matrix-bound ligand with which the enzyme is associated. Bio-specific elution is not always possible, in which case elution can be stimulated by, for example, using a gradient of increasing salt concentration or by changing the $\mathrm{pH}$-value of the elution buffer.

Because bio-affinity chromatography makes use of specific interactions, it may result in a high degree of purification. In some cases, using this technique, an enzyme can be obtained from a crude extract almost completely pure in a single chromatographic step (see example of Old Yellow Enzyme given below). However, commercially available bio-affinity resins are often very costly and have a limited choice in coupled ligands. In addition, these resins are also not easily prepared "at home," especially when expensive biomolecules must be used as immobilized ligands. Bio-affinity columns containing such ligands are usually more difficult to clean than, e.g., ion exchangers; therefore, the lifetime of a bio-affinity column is often limited.

We applied traditional bio-affinity chromatography for the purification of a number of enzymes, ranging from oxidoreductases to transferases. For 4-hydroxybenzoate 3-hydroxylase, we developed a Cibacron Blue dye affinity matrix, which appeared to be very useful for increasing the specific activity and yield of the enzyme, as isolated from different microbial sources $[14,15,19-21]$. Glutathione $S$-transferase isoenzymes from rat liver were purified using $S$-hexylglutathione affinity chromatography, followed by chromatofocusing on a Mono-P column [53]. A novel branched-chain alcohol dehydrogenase was purified from Saccharomyces cerevisiae using a Procion Red dye affinity column, which was selected based on its capacity to bind to a wide range of nicotinamide adenine dinucleotide phosphate (NADP)-dependent enzymes [36].

Old Yellow Enzyme from Saccharomyces carlsbergensis is the canonical member of a large family of ene reductases [54]. These flavoenzymes catalyze the asymmetric transhydrogenation of alkenes, resulting in industrially relevant chiral products [55]. Because Old Yellow Enzyme strongly interacts with phenolic compounds that act as competitive inhibitors, the enzyme was purified originally in high yield from brewer's bottom yeast by affinity chromatography using $N$-(4-hydroxybenzoyl)aminohexyl agarose [56-58]. This affinity matrix was prepared from agarose in four steps [56]: 
(1) Agarose beads were equipped with an aminohexyl spacer arm by activating the beads with cyanogen bromide in the presence of 1,6-diaminohexane.

(2) The resulting aminohexyl agarose was reacted with 4-acetoxybenzoic acid to give $\mathrm{N}$-(4-acetoxybenzoyl)aminohexyl agarose.

(3) Remaining free amino groups were acetylated with acetic anhydride.

(4) The protecting acetoxy group was removed from the ligand by incubation with imidazole, yielding the $\mathrm{N}$-(4-hydroxybenzoyl)aminohexyl agarose affinity matrix (Figure 1.6).

The purification of Old Yellow Enzyme from brewer's bottom yeast then went as follows [56]:

(1) $350 \mathrm{~g}$ dried yeast was suspended in 11 of demineralized water, containing $10 \mu \mathrm{M}$ phenylmethylsulfonylfluoride to inactivate serine proteases.

(2) The suspension was homogenized for 30 seconds at the high-speed setting of a Waring Blendor.

(3) Autolysis: the mixture was transferred to a glass beaker and mechanically stirred for 4 hours at $37^{\circ} \mathrm{C}$. All subsequent operations were performed at $0-4^{\circ} \mathrm{C}$.

(4) The extract was clarified by centrifugation and precipitated with solid ammonium sulfate to $78 \%$ saturation.

(5) Enzyme reduction to remove phenolic ligands: the precipitate was collected by centrifugation and dialyzed overnight against 61 of $0.1 \mathrm{M}$ Tris- $\mathrm{HCl} \mathrm{pH} \mathrm{8.0,} \mathrm{containing}$ $0.1 \mathrm{M}$ ammonium sulfate, $10 \mu \mathrm{M}$ phenylmethylsulfonylfluoride, and $10 \mathrm{mM}$ sodium dithionite.

(6) Enzyme reoxidation: dialysis with the same buffer, omitting sodium dithionite, continued for another 6 hours with one additional buffer change.

(7) Centrifugation to remove a white precipitate and stirring the clarified yeast extract for another 30 minutes to ensure reoxidation.

(8) A column of $N$-(4-hydroxybenzoyl)aminohexyl agarose (Figure 1.6, bed volume $20 \mathrm{ml}$ ) was washed with $0.1 \mathrm{M}$ Tris- $\mathrm{HCl} \mathrm{pH} 8.0$, containing $0.1 \mathrm{M}$ ammonium sulfate and $10 \mu \mathrm{M}$ phenylmethylsulfonylfluoride.

(9) The clarified yeast extract was applied on the column and the column was extensively washed with buffer (about 21) until the absorbance at $280 \mathrm{~nm}$ is lower than 0.2 .

(10) The Old Yellow Enzyme was eluted with $400 \mathrm{ml}$ of washing buffer, which was degassed, flushed with oxygen-free nitrogen, and supplemented with $3 \mathrm{mM}$ sodium dithionite.

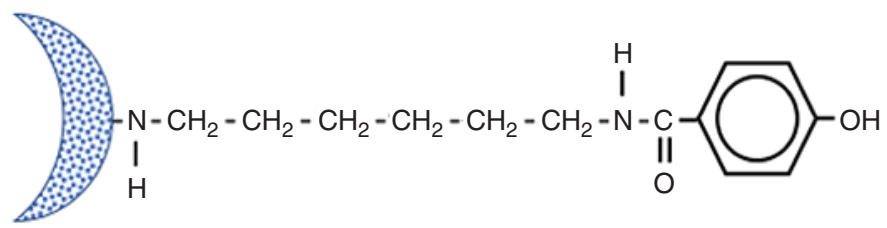

Figure $1.6 \mathrm{~N}$-(4-Hydroxybenzoyl)aminohexyl agarose affinity matrix. 
(11) The enzyme eluted directly upon flavin reduction and turned bright yellow after reoxidation by air.

(12) The collected enzyme (about $100 \mathrm{ml}$ ) was concentrated by ultrafiltration and stored frozen in $1 \mathrm{ml}$ aliquots.

(13) Regeneration of the affinity matrix was accomplished by washing the agarose beads with $0.2 \mathrm{M}$ acetate buffer $\mathrm{pH} 5.0$, containing $6 \mathrm{M} \mathrm{GuHCl}$.

(14) Storage of the gel in $10 \%$ ethanol with $1 \mathrm{mM}$ sodium azide to prevent microbial damage.

SDS-PAGE showed that the Old Yellow Enzyme from $S$. carlsbergensis (relative subunit molecular mass $=49 \mathrm{kDa}$ ) was obtained in pure form. Absorption spectral analysis confirmed that the dimeric enzyme contained one tightly bound molecule of flavin mononucleotide (FMN) per subunit. The yield of enzyme was about $85 \%(130 \mathrm{mg})$ and its specific activity (turnover number) was slightly higher than the value obtained for the enzyme purified by conventional procedures.

Besides IEC, there are other chromatographic separation methods that make use of the properties of a protein's surface for adsorption to a specific chromatographic resin. The most commonly applied methods are described below.

\subsubsection{Hydrophobic Interaction Chromatography}

HIC is a very useful technique for the fractionation of proteins [59]. In proteins, some hydrophobic groups, or clusters of hydrophobic groups, can occur at the surface of a protein and thus contribute to the surface hydrophobicity. The surface hydrophobicity allows a protein to undergo hydrophobic interactions not only with other proteins but also with column materials carrying hydrophobic groups.

Hydrophobic interactions between nonpolar compounds are enhanced by a polar environment and are energetically favorable because of a gain in entropy on forming. It is the liberation of ordered water molecules in contact with hydrophobic surfaces that drives clustering of hydrophobic groups. It follows that hydrophobic interactions will be affected if the structure of water is changed by dissolved salts or organic solvents. Kosmotropic salts (e.g. ammonium sulfate) tend to favor the strength of hydrophobic interactions, whereas chaotropic salts (e.g. sodium thiocyanate) disrupt the structure of water and thus tend to decrease the strength of hydrophobic interactions. Organic solvents are also commonly used to alter the polarity of water.

Although the mechanisms of hydrophobic interactions are complicated, chromatographic techniques based on hydrophobic interactions are easy to use. The most common resins for HIC are substituted with $n$-butyl, $n$-octyl, or phenyl groups. For an uncharacterized protein, as a start, phenyl-substituted resin is usually the best choice because strongly hydrophobic proteins are not easily eluted from the highly hydrophobic octyl-substituted resins. The phenyl ligand is intermediate in hydrophobicity between $n$-butyl and $n$-pentyl and will bind to aromatic amino acids through $\pi-\pi$ interactions.

A salt concentration just below that used for salting out of a protein is normally used for binding the protein to a hydrophobic matrix. A common procedure is to start purification of a protein from a crude extract with an ammonium sulfate precipitation at a 
concentration of ammonium sulfate that leaves the protein of interest just in solution, followed by removal of proteins that precipitate at this salt concentration by centrifugation, and loading the clarified extract onto an HIC column.

Proteins bound to an HIC column are eluted by reducing the concentration of kosmotropic salt (e.g. ammonium sulfate) in the buffer using a negative gradient. This successively releases proteins from the column in order of hydrophobicity. Proteins that are tightly bound such that they do not elute at zero salt concentration can be eluted using a positive gradient of a polarity-reducing organic solvent (usually up to 50\% ethylene glycol).

We applied the HIC technology in quite some traditional enzyme purifications, usually after ammonium sulfate fractionation, and often in combination with IEC and an additional chromatographic step. This enabled us to characterize the catalytic properties of several oxidoreductases [12-14, 23, 24, 27, 33, 37, 39, 60, 61] (see also Table 1.2).

A special case of HIC concerns the purification of the recombinant forms of lipoamide dehydrogenase from $A$. vinelandii [62] and P. fluorescens [63]. Both these enzymes, overproduced in Escherichia coli, could be purified in a single chromatographic step by binding them to a Sepharose 6B gel filtration column, equilibrated in $0.1 \mathrm{M}$ potassium phosphate buffer $\mathrm{pH} 7.0$, containing ammonium sulfate at $50 \%$ saturation. After washing with equilibration buffer, the lipoamide dehydrogenases were obtained in pure form by eluting with the same buffer at $25 \%$ ammonium sulfate saturation.

We also applied the HIC technology for the reversible removal of the flavin cofactor in a number of flavoproteins, including lipoamide dehydrogenase, glutathione reductase, mercuric reductase, and butyryl-CoA dehydrogenase [64, 65]. Figure 1.7 presents a schematic overview of the procedures. Each flavoprotein is bound to Phenyl Sepharose in a high-salt buffer. After changing to low $\mathrm{pH}$, the FAD cofactor is released from the bound protein. Reconstitution of holoenzyme with natural FAD, chemically modified FAD, or isotopically enriched FAD (FAD*) is performed on-column at neutral pH. Next, the reconstituted protein is released from the column with 50\% ethylene glycol. Alternatively, the apoprotein is released from the column with $50 \%$ ethylene glycol and the holoenzyme is reconstituted in solution. The HIC technology appeared to be superior to classical methods for the reversible dissociation of the FAD cofactor of these enzymes, especially because the reversible immobilization procedure gave excellent yields and could be applied at large scale.

\subsubsection{Hydroxyapatite Chromatography}

Another adsorption chromatography method for enzyme purification concerns hydroxyapatite (HAP) chromatography [66]. HAP is a chromatographic support consisting of calcium phosphate crystals.

The amino groups of proteins adsorb to HAP primarily as a result of nonspecific electrostatic interactions between their positive charges and negative charges on the HAP column when the column is equilibrated with phosphate buffer. The carboxyl groups in proteins bind specifically by complexation to the calcium sites on the column. It was also found that basic proteins are eluted either as a result of normal DebyeHückel charge screening or by a specific displacement with $\mathrm{Ca}^{2+}$ and $\mathrm{Mg}^{2+}$ ions, which 


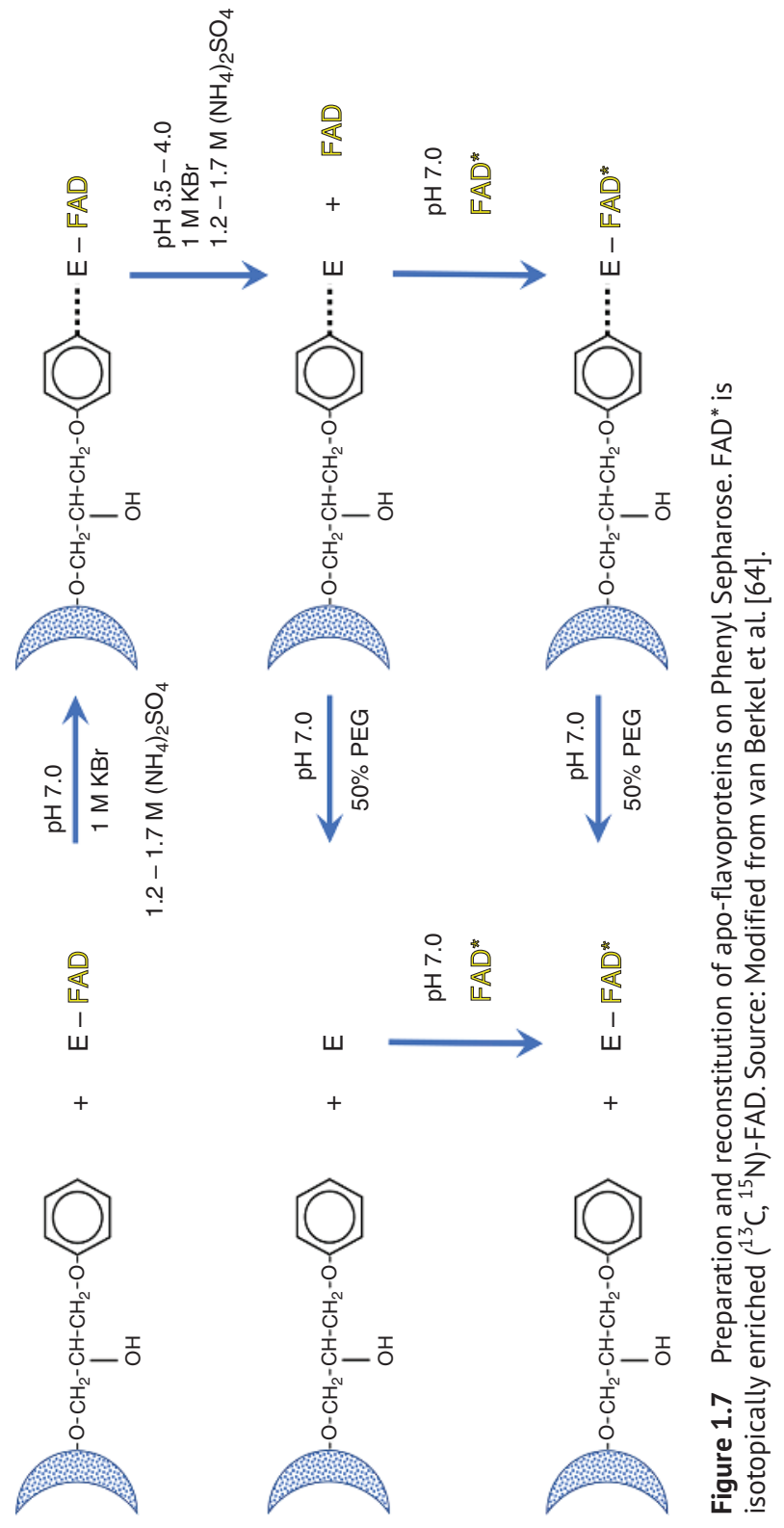


form a complex with column phosphates and neutralize their negative charges. Acidic proteins are eluted by displacement of their carboxyl groups from calcium sites by ions that form stronger complexes with calcium than do carboxylate groups, e.g. fluoride or phosphate. The ineffectiveness of chloride as an eluent of acidic proteins is due to the fact that it does not form a complex with $\mathrm{Ca}^{2+}$ and, thus, cannot compete with the calcium carboxylate complexes. The ability of $\mathrm{CaCl}_{2}$ and $\mathrm{MgCl}_{2}$ to strengthen the interaction of acidic proteins with HAP is due to the formation of additional bridges between protein carboxyl groups and column phosphate sites. In practice, proteins are often applied in 5-10 mM phosphate buffer at pH 7.0 and eluted with an increasing gradient of phosphate buffer.

We successfully applied HAP chromatography for the purification of vanillyl alcohol oxidase [13, 60], NADH reductase [35], catalase peroxidase [12], 4-hydroxybenzoate 3-hydroxylase [20], 4-hydroxybenzoate 1-hydroxylase [61], carveol dehydrogenase [37], flavin reductase PheA2 [25], and galactonolactone oxidoreductase [39] (see also Table 1.2). In most cases, HAP chromatography was introduced at the final stage of purification, after IEC or HIC, and before SEC.

\subsection{Example of a Traditional Enzyme Purification Protocol}

We already discussed the theoretical aspects and some specific applications of the traditional enzyme purification methods. In this paragraph, we describe the purification of 3-hydroxyphenylacetate 6-hydroxylase from Flavobacterium JS-7 as an example of a traditional enzyme purification protocol [23].

(1) $50 \mathrm{~g}$ of Flavobacterium JS-7 cells, grown with $0.1 \%$ phenylacetic acid as a sole source of carbon and energy, was suspended in $10 \mathrm{mM}$ potassium phosphate at $\mathrm{pH} 7.0$, containing $0.5 \mathrm{mM}$ ethylenediaminetetraacetic acid (EDTA) (for complexation of heavy metal ions), $0.5 \mathrm{mM}$ dithiothreitol (DTT) (to prevent cysteine oxidation), 1.5 mM 3-hydroxyphenylacetic acid (binding of this aromatic substrate in the active site might protect the enzyme from inactivation), and $10 \mu \mathrm{M}$ FAD (to prevent apoenzyme formation). Next, $1 \mathrm{mg}$ of DNase was added and cells were broken in a precooled French Press. The resulting cell extract was clarified by centrifugation at $4{ }^{\circ} \mathrm{C}$. All further operations were performed between 0 and $4{ }^{\circ} \mathrm{C}$ using the abovementioned starting buffer omitting the aromatic substrate. After each chromatographic step, the enzyme solution was concentrated by ultrafiltration and desalted through either dialysis or gel filtration before performing the next step.

(2) Cell extract, containing about $3 \mathrm{~g}$ of protein, was loaded onto a DEAE-Sepharose CL-6B column $(17 \times 2.4 \mathrm{~cm}$; bed volume $77 \mathrm{ml})$. After washing with five volumes of starting buffer, the enzyme was eluted with a $0-0.5 \mathrm{M} \mathrm{KCl}$ gradient in $1000 \mathrm{ml}$ of starting buffer. Pooled active fractions eluting between 0.10 and $0.15 \mathrm{M} \mathrm{KCl}$ were loaded onto a Phenyl Sepharose CL-4B column $(2.4 \times 9 \mathrm{~cm}$; bed volume $41 \mathrm{ml})$, equilibrated with $15 \%$ ammonium sulfate. After washing with five volumes of equilibration buffer, the enzyme was eluted with a decreasing gradient of 15 to $0 \%$ ammonium sulfate in $500 \mathrm{ml}$ starting buffer. Pooled active fractions eluting between 8.4 and $0 \%$ ammonium sulfate were 
Table 1.3 Purification of 3-hydroxyphenylacetate 6-hydroxylase from Flavobacterium JS-7.

\begin{tabular}{lllcl}
\hline Step & Activity (U) & Protein $(\mathbf{m g})$ & Spec. activity $\left(\mathbf{U ~ m g}^{-1}\right)$ & Yield (\%) \\
\hline CE & 1050 & 3080 & 0.3 & 100 \\
IEC & 799 & 250 & 3.2 & 76 \\
HIC & 712 & 60 & 11.9 & 68 \\
BAC & 510 & 28 & 18.2 & 49 \\
\hline
\end{tabular}

Source: Adapted from Van Berkel and van den Tweel [23].

Steps: CE, cell extract; IEC, ion exchange chromatography; HIC, hydrophobic interaction chromatography; BAC, bio-affinity chromatography.

loaded onto a Reactive Red 120 agarose column $(2.4 \times 9 \mathrm{~cm}$; bed volume $41 \mathrm{ml})$. After washing with five volumes of starting buffer, the enzyme was eluted with a linear gradient of $0-1 \mathrm{M} \mathrm{KCl}$ in $500 \mathrm{ml}$ starting buffer. Pooled active fractions eluting between 0.16 and $0.46 \mathrm{M} \mathrm{KCl}$ were concentrated in $50 \mathrm{mM}$ starting buffer, and $1 \mathrm{ml}$ aliquots with a protein concentration of $2 \mathrm{mg} \mathrm{ml}^{-1}$ was distributed over Eppendorf tubes, flash frozen in liquid nitrogen, and stored at $-70^{\circ} \mathrm{C}$. The results of this purification procedure are summarized in Table 1.3.

\subsection{Purification of Recombinant Enzymes}

Developments in recombinant DNA technology and genome sequencing at the turn of the millennium have led to new procedures for the discovery and production of biocatalysts (see also Chapter 2). Nowadays, most biocatalysts are produced in heterologous hosts through the expression of synthetic genes. Many strategies for the expression of these recombinant proteins exist [67-69]. Many new biocatalysts are produced as fusion proteins, either to allow their rapid and efficient purification, enhance their proper folding and solubility, or facilitate cofactor regeneration [70].

One of the most widely applied methods for the purification of recombinant proteins concerns immobilized metal affinity chromatography (IMAC). This versatile method is described in the following section.

\subsubsection{Immobilized Metal Affinity Chromatography}

IMAC is a specialized adsorption chromatography technique that has turned into a powerful tool for single-step purification of recombinant proteins into which a metal binding site ("His-tag") has been manufactured by genetic modification [71]. In IMAC, transition metal ions such as cobalt, nickel, or zinc act as electron acceptors (Lewis acids) for groups with electron-donating atoms (Lewis bases). The imidazole nitrogen atoms of His-tags introduced at the $\mathrm{N}$ - or $\mathrm{C}$-terminal ends of proteins appear to be perfect electron donors for these metal ions. 
In order to utilize this interaction for chromatographic purposes, the metal ion must be immobilized onto an insoluble support. The most widely applied chelating group for that is nitrile-triacetic acid (NTA), which has four bases for binding a nickel ion.

Binding of proteins to IMAC columns is usually best between $\mathrm{pH} 6.0$ and $\mathrm{pH} 8.0$ where the imidazole groups of the histidine residues are deprotonated. Chelating agents such as EDTA or citrate, but also Tris buffer, can reduce the binding strength. In order to prevent a metal affinity column to also function as an ion exchanger, buffers for loading, washing, and eluting proteins usually contain a relatively high ionic strength.

His-tags can be inserted at the $\mathrm{N}$ - or C-terminal ends of proteins or within exposed loops. The tag is added by modification of the gene encoding the protein to include codons for 6 to 10 consecutive histidine residues. These codons can be added by site-directed mutagenesis or by cloning the gene directly, in the correct reading frame, into a vector that contains these codons, resulting in a fusion protein. It is of major importance that the inserted histidine residues do not prohibit proper folding of the protein nor interfere with its enzyme activity. Site-directed mutagenesis also facilitates removal of His-tags after purification of the protein. This is commonly done by insertion of a recognition site for a highly specific endopeptidase between His-tag and native protein.

Ni-NTA metal affinity columns have a high binding capacity (5-10 mg protein per $\mathrm{ml}$ packed gel). His-tagged proteins bound to Ni-NTA are eluted from the column by inclusion of a high-concentration (250-500 mM) imidazole in the elution buffer. Before eluting Histagged proteins, it is worth washing the column with a low concentration of imidazole $(10-50 \mathrm{mM})$ in order to remove weakly interacting proteins.

We used the His-tag technology for the purification of several oxidoreductases including galactonolactone dehydrogenase from Arabidopsis thaliana [72], styrene monooxygenase from $R$. opacus 1CP [73, 74], 3-hydroxybenzoate 6-hydroxylase from Rhodococcus jostii RHA1 and Pseudomonas alcaligenes [26, 75], ene reductase from $R$. opacus CP1 [76], pyranose 2-oxidase from Arthrobacter siccitolerans [77], styrene monooxygenase reductase from $R$. opacus 1CP [78], vanillyl alcohol oxidase from $P$. simplicissimum [79], eugenol oxidase from Rhodococcus jostii RHA1 [80], 5-(hydroxymethyl)furfural oxidase from Methylovorus sp. strain MP688 [81, 82], and 4-hydroxybenzoate hydroxylase from Cupriavidus necator [83].

The hyperthermostable laminarinase from Pyrococcus furiosus (LamA) was also purified using the His-tag technique. The cell-fee extract, obtained after breaking overexpressing E. coli cells and subsequent centrifugation, was subjected to Ni-NTA affinity chromatography, in which the LamA was eluted with a linear gradient of 0-0.5 M imidazole [42]. Next to highly active monomers, a minor part of the soluble enzyme constituted less active native-like oligomers and non-native monomers.

It is important to mention here that almost $50 \%$ of the overproduced LamA protein ended up in the pellet fraction that was obtained after initial centrifugation of the lysed cells. Notably, a large fraction of the soluble and insoluble LamA aggregates could be recovered in fully active form by incubating them for several hours at $80^{\circ} \mathrm{C}$ in the presence of $3 \mathrm{M}$ guanidine hydrochloride $(\mathrm{GuHCl})$. Similar chaotropic heat treatment protocols might be useful for increasing the yield of other hyperthermostable enzymes that tend to aggregate during production in E. coli. 
Obviously, this method is not applicable to less thermotolerant enzymes that initially are produced in inclusion bodies. For such His-tagged proteins, a soluble enzyme exhibiting the desired activity might be obtained by solubilizing them with a proper unfolding agent and subsequent purifying and refolding using a Ni-NTA affinity matrix [84].

Care must be taken regarding the correct unfolding and refolding conditions. For instance, for aryl-alcohol oxidase from Pleurotus eryngii overproduced in E. coli (without His-tag), the washed inclusion bodies were first solubilized in $20 \mathrm{mM}$ Tris-HCl buffer at pH 8.0, containing $2 \mathrm{mM}$ EDTA, $30 \mathrm{mM}$ DTT, and $8 \mathrm{M}$ urea. Next, optimization of the refolding conditions yielded a decently active enzyme after incubating the recombinant protein at $0.4 \mathrm{mg} \mathrm{ml}^{-1}$ for 80 hours at $16^{\circ} \mathrm{C}$ and $\mathrm{pH} 9.0$ in the presence of $35 \%$ glycerol, $80 \mu \mathrm{M}$ FAD, $0.6 \mathrm{M}$ urea, $1 \mathrm{mM}$ DTT, $2.5 \mathrm{mM}$ oxidized glutathione, and $1.25 \mathrm{mM}$ reduced glutathione [85].

Recently, Fraaije and coworkers used the IMAC technology for the purification of a selfsufficient cytochrome P450 monooxygenase from Thermothelomyces thermophila [86]. They also developed experimental protocols for screening of thermostable Baeyer-Villiger monooxygenases by purifying the His-tagged proteins with Ni-NTA beads in a 96-well plate format [87]. Robust cyclohexanone monooxygenases, stabilized by applying mutations found by computational and experimental library design, were characterized after purification by metal affinity chromatography [88].

A special application of Ni-NTA affinity chromatography concerns the deflavinylation and reconstitution of flavoproteins [89]. This generic method, originally developed for the NifL PAS domain from A. vinelandii [89], also turned out to be very useful for the reversible resolution of flavin and pterin cofactors of His-tagged E. coli DNA photolyase [90].

\subsubsection{Affinity Chromatography with Protein Tags}

Next to IMAC, affinity chromatography procedures are available for enzyme purification that make use of a specific interaction of protein tags with accompanying resins. Wellknown examples of such fusion tags are thioredoxin (Trx), glutathione transferase (GST), maltose binding protein (MBP), and small ubiquitin modifier (SUMO) [70]. These so-called solubility tags fold rapidly into a stable and highly soluble protein upon translation and fusion to the $\mathrm{N}$-terminus of the enzyme of interest might stimulate the expression and solubility of the target enzyme. Again, removal of the tag from the purified protein can be facilitated by insertion of a recognition site for a highly specific endopeptidase between the tag and the native protein.

Dijkman and Fraaije used the SUMO technology for the production of 5-(hydroxymethyl)furfural oxidase (HFMO) from Methylovorus sp. strain MP688 [81]. To that end, they designed a His $_{6}$-SUMO-HFMO gene construct, which, after ligation in a pET-SUMO vector, could be expressed in E. coli BL21(DE3) cells. After production, the His ${ }_{6}$-SUMO-HMFO fusion was cleaved with $\mathrm{His}_{6}$-SUMO protease. Subsequently, a Ni-NTA column was used to capture both the $\mathrm{His}_{6}$-SUMO tag and $\mathrm{His}_{6}$-SUMO protease, yielding purified HMFO in the flow through. A similar strategy was applied for the production of Thermocrispum municipale cyclohexanone monooxygenase (TmCHMO) variants, with the aim of selecting for variants of TmCHMO with changed stereo- and regioselectivity [91, 92] and substrate preference [93]. 
The gene coding for polycyclic ketone monooxygenase (PockeMO) from Thermothelomyces thermophila was fused into a $\mathrm{His}_{6}$-SUMO-containing $\mathrm{pET}$ vector (yielding pET-His ${ }_{6}$-SUMO-PockeMO) and also into a $\mathrm{His}_{6}$ cofactor-recycling phosphite dehydrogenase $(\mathrm{PTDH})$ containing the $\mathrm{pBAD}$ vector (yielding $\mathrm{pBAD}-\mathrm{His}_{6}-\mathrm{PTDH}$-linker-PockeMO) by Fraaije and coworkers [94]. For the expression of the SUMO fusion, E. coli BL21(DE3) was used and for expression of the PTDH fusion, E. coli NEB10 $\beta$ cells were used. Both constructs yielded high expression levels and the fusion proteins were easily purified with Ni-NTA affinity chromatography by exploiting the $\mathrm{N}$-terminal $\mathrm{His}_{6}$-tags. PockeMO is active with bulky ketones and can perform enantioselective oxidations on steroids. The PTDH-PockeMO protein showed an increased activity compared to the native enzyme. After removal of the SUMO tag, applying the method described above for TmCHMO, the protein could be crystallized and its structure solved. PockeMO exhibits the typical Bayer-Villiger monooxygenase organization with an FAD domain, an NADP domain, and a helical domain [94].

Fraaije and coworkers also showed that the flavoprotein alditol oxidase (AldO) from Streptomyces coelicolor is expressed at extremely high levels in E. coli when the enzyme is fused to MBP [95]. The extreme overproduction of the fused protein allowed for a single-step purification procedure using a Q-Sepharose ion exchanger. To find out if fused MBP-AldO protein behaves similarly to native AldO, the MBP tag was cleaved off with trypsin. Using amylose affinity chromatography, the MBP tag was removed. Electrospray ionization mass spectrometry analysis of free AldO established that cleavage had occurred at the expected site and that a homogeneous AldO preparation was obtained. AldO turned out to be active with the same range of substrates as found for fused MBP-AldO protein. AldO accepts various polyols, with xylitol and sorbitol being the preferred substrates. Intriguingly, AldO also oxidizes thiols such as DTT to the corresponding thiocarbonyls [82].

Incorporation of an N-terminal MBP solubility tag strongly increased the yield of recombinant form of the membrane-associated proline dehydrogenase from T. thermophilus (TtProDH) [37]. Expressed MBP-TtProDH comprised about 50\% of the total protein content of expressing E. coli cells, and by applying amylose affinity chromatography, more than $250 \mathrm{mg}$ of active enzyme was obtained per liter of culture. Native TtProDH was obtained by cleaving the fusion protein with trypsin in the presence of the detergent $n$-octyl $\beta$-D-glucopyranoside. Analytical gel filtration suggested that both native and MBP-fused TtProDH form tetramers that are prone to aggregation through non-native self-association. Site-directed mutagenesis (F10E/L12E variant) then showed that the hydrophobic N-terminal helix of ProDH is responsible for the self-association process [96]. Truncation of the $\mathrm{N}$-terminal arm of $T t \operatorname{ProDH}(\Delta \mathrm{A}$ and $\Delta \mathrm{AB}$ variants) resulted in highly active tetramers [50], while selective disruption of two ion pairs in the dimerization interface of the enzyme (D205K/E207K variants) resulted in monomer formation (Figure 1.8) [51]. The newly created $T t$ ProDH monomer showed excellent catalytic properties but a significant lower thermal stability than the tetramer. Finally, using a riboflavin auxotrophic E. coli strain and MBP as a solubility tag, we also succeeded in producing the apoprotein of TtProDH. Reconstitution experiments together with structural studies and flavin content analysis led to the surprising conclusion that TtProDH does not discriminate between FAD and FMN as a cofactor [97]. 
EE

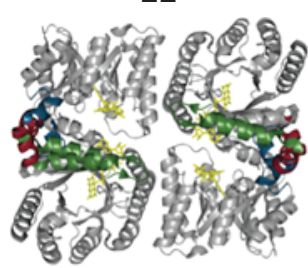

KK

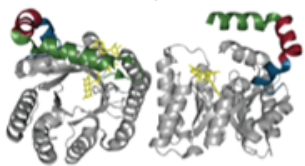

$\Delta \mathrm{A}$
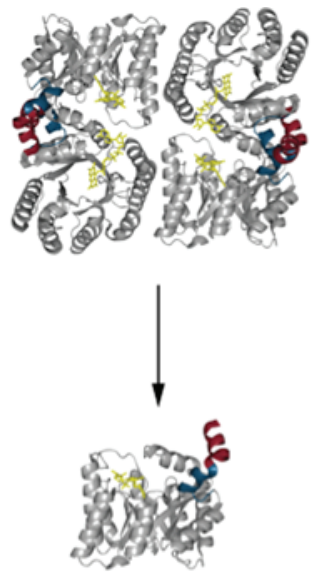

$\triangle \mathrm{AB}$
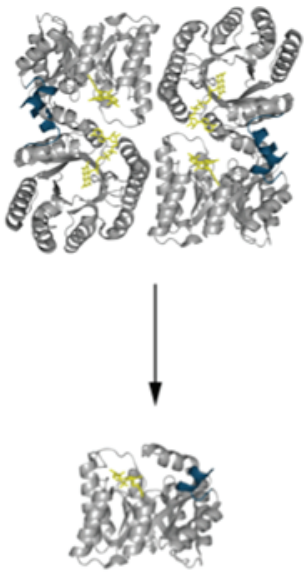

Figure 1.8 Oligomeric state of TtProDH and its site-directed mutants. EE: F10E/L12E variant. $\triangle \mathrm{A}: T t$ ProDH without the $\mathrm{N}$-terminal helix $\alpha \mathrm{A} . \triangle \mathrm{AB}$ : TtProDH without the $\mathrm{N}$-terminal helices $\alpha \mathrm{A}$ and $\alpha B$. KK: D205K/E207K variants of EE, $\Delta A$ and $\triangle A B$. The flavin cofactor is shown in yellow, helix $\alpha A$ in green, helix $\alpha B$ in red, and helix $\alpha C$ in blue. Source: Modified from Huijbers et al. [51].

\subsection{Column Materials}

A small selection of commercially available column materials is shown in Table 1.4. These bulk resins can be used to construct columns of various sizes in accordance with the type and volume of samples applied. In addition, a large number of prepacked columns for direct use are also available from these companies.

Table 1.4 Selection of various commercially available chromatography media.

\begin{tabular}{|c|c|c|c|c|}
\hline lon exchange & Matrix & Functional group & $\begin{array}{l}\text { Capacity } \\
\left(\mathrm{mg} \mathrm{ml}^{-1}\right)\end{array}$ & Brand \\
\hline Capto Q & $\begin{array}{l}\text { Highly cross-linked } \\
\text { agarose with a dextran } \\
\text { surface extender }\end{array}$ & $\begin{array}{l}\text { Quaternary } \\
\text { amine }\end{array}$ & High & 1 \\
\hline Capto S & $\begin{array}{l}\text { Highly cross-linked } \\
\text { agarose with a dextran } \\
\text { surface extender }\end{array}$ & Sulfonate group & High & 1 \\
\hline Source 15Q & $\begin{array}{l}\text { Rigid polystyrene - a } \\
\text { divinyl benzene polymer }\end{array}$ & $\begin{array}{l}\text { Quaternary } \\
\text { amine }\end{array}$ & High & 1 \\
\hline Source 15S & $\begin{array}{l}\text { Rigid polystyrene - a } \\
\text { divinyl benzene polymer }\end{array}$ & Sulfonate group & High & 1 \\
\hline Macro-Prep High Q & Methacrylate copolymer & $\begin{array}{l}\text { Quaternary } \\
\text { amine }\end{array}$ & $37 \mathrm{BSA}$ & 2 \\
\hline
\end{tabular}


Table 1.4 (Continued)

\begin{tabular}{|c|c|c|c|c|}
\hline lon exchange & Matrix & Functional group & $\begin{array}{l}\text { Capacity } \\
\left(\mathrm{mg} \mathrm{ml}^{-1}\right)\end{array}$ & Brand \\
\hline Macro-Prep High S & Methacrylate copolymer & Sulfonate group & $49 \mathrm{IgG}$ & 2 \\
\hline Macro-Prep DEAE & Methacrylate copolymer & $\begin{array}{l}\text { Diethylamino- } \\
\text { ethyl }\end{array}$ & $40 \mathrm{BSA}$ & 2 \\
\hline Macro-Prep CM & Methacrylate copolymer & Carboxy methyl & $40 \mathrm{BSA}$ & 2 \\
\hline Gel filtration & Matrix & $\begin{array}{l}\text { Separation } \\
\text { range (kDa) }\end{array}$ & & Brand \\
\hline Sephacryl S-100 HR & $\begin{array}{l}\text { Copolymer of allyl } \\
\text { dextran and } N, N^{\prime}- \\
\text { methylene bisacrylamide }\end{array}$ & $1-100$ & & 1 \\
\hline Sephacryl S-200 HR & $\begin{array}{l}\text { Copolymer of allyl } \\
\text { dextran and } N, N^{\prime}- \\
\text { methylene bisacrylamide }\end{array}$ & $5-250$ & & 1 \\
\hline Sephacryl S-500 HR & $\begin{array}{l}\text { Copolymer of allyl } \\
\text { dextran and } N, N^{\prime}- \\
\text { methylene bisacrylamide }\end{array}$ & $40-20000$ & & 1 \\
\hline $\begin{array}{l}\text { Superdex } 75 \text { Prep } \\
\text { Grade }\end{array}$ & $\begin{array}{l}\text { Composite of cross-linked } \\
\text { agarose and dextran }\end{array}$ & $3-70$ & & 1 \\
\hline $\begin{array}{l}\text { Superdex } 200 \text { Prep } \\
\text { Grade }\end{array}$ & $\begin{array}{l}\text { Composite of cross-linked } \\
\text { agarose and dextran }\end{array}$ & $10-600$ & & 1 \\
\hline Bio-Gel P-30 & $\begin{array}{l}\text { Copolymerization of } \\
\text { acrylamide and } N, N^{\prime} \text { - } \\
\text { methylenebisacrylamide } \\
\text { gel }\end{array}$ & $2.4-40$ & & 2 \\
\hline Bio-Gel P-100 & $\begin{array}{l}\text { Copolymerization of } \\
\text { acrylamide and } N, N^{\prime}- \\
\text { methylenebisacrylamide } \\
\text { gel }\end{array}$ & $5-100$ & & 2 \\
\hline Bio-Gel A 1.5 m & Agarose & $10-1500$ & & 2 \\
\hline (Bio)-affinity & Matrix & $\begin{array}{l}\text { Functional } \\
\text { group }\end{array}$ & $\begin{array}{l}\text { Capacity } \\
\left(\mathrm{mg} \mathrm{ml}^{-1}\right)\end{array}$ & Brand \\
\hline HiPrep Heparin FF & Cross-linked $6 \%$ agarose & Heparin & High & 1 \\
\hline Ni Sepharose HP & $\begin{array}{l}\text { Highly cross-linked } \\
\text { agarose }\end{array}$ & Ni-charged & 40 & 1 \\
\hline $\begin{array}{l}\text { Glutathione } \\
\text { Sepharose } 4 \text { FF }\end{array}$ & $\begin{array}{l}\text { Highly cross-linked } 4 \% \\
\text { agarose }\end{array}$ & Glutathione & 10 & 1 \\
\hline $\begin{array}{l}\text { Strep-Tactin }{ }^{\circledR} \mathrm{XT} \\
\text { Sepharose }\end{array}$ & Rigid cross-linked agarose & Strep-Tactin & 10 & 1 \\
\hline $\begin{array}{l}\text { Blue Sepharose } 6 \\
\text { Fast Flow }\end{array}$ & Cross-linked $6 \%$ agarose & Cibacron blue $3 \mathrm{G}$ & High & 1 \\
\hline Nuvia $^{\mathrm{TM}}$ IMAC & Inert hydrophilic beads & $\begin{array}{l}\text { Nitrilotriacetic } \\
\text { acid }\end{array}$ & $>40$ & 2 \\
\hline
\end{tabular}


Table 1.4 (Continued)

\begin{tabular}{|c|c|c|c|c|}
\hline lon exchange & Matrix & Functional group & $\begin{array}{l}\text { Capacity } \\
\left(\mathrm{mg} \mathrm{ml}^{-1}\right)\end{array}$ & Brand \\
\hline Affi-Gel ${ }^{\circledR}$ Blue Gel & Cross-linked agarose & $\begin{array}{l}\text { Cibacron blue } \\
\text { F3GA }\end{array}$ & $>11$ & 2 \\
\hline $\begin{array}{l}\text { Hydrophobic } \\
\text { interaction }\end{array}$ & Matrix & $\begin{array}{l}\text { Functional } \\
\text { group }\end{array}$ & $\begin{array}{l}\text { Capacity } \\
\left(\mathrm{mg} \mathrm{ml}^{-1}\right)\end{array}$ & Brand \\
\hline $\begin{array}{l}\text { Phenyl Sepharose } 6 \\
\text { FF }\end{array}$ & Cross-linked $6 \%$ agarose & Phenyl & High & 1 \\
\hline Butyl Sepharose 4 FF & Cross-linked $4 \%$ agarose & Butyl & High & 1 \\
\hline Octyl Sepharose 4 FF & Cross-linked $4 \%$ agarose & Octyl & High & 1 \\
\hline $\begin{array}{l}\text { Macro-Prep }{ }^{\circledR} \text { Methyl } \\
\text { HIC }\end{array}$ & Methacrylate & Methyl & 12 & 2 \\
\hline $\begin{array}{l}\text { Macro-Prep } t \text {-butyl } \\
\text { HIC }\end{array}$ & Methacrylate & $t$-Butyl & 12 & 2 \\
\hline $\begin{array}{l}\text { Hydroxyapatite } \\
\text { interaction }\end{array}$ & Matrix & $\begin{array}{l}\text { Functional } \\
\text { group }\end{array}$ & $\begin{array}{l}\text { Capacity } \\
\left(\mathrm{mgg}^{-1}\right)\end{array}$ & Brand \\
\hline $\begin{array}{l}\text { Bio-Gel }{ }^{\circledR} \text { HT } \\
\text { Hydroxyapatite }\end{array}$ & Calcium phosphate & $\begin{array}{l}\text { Calcium } \\
\text { phosphate }\end{array}$ & $10 \mathrm{BSA}$ & 2 \\
\hline
\end{tabular}

1. GE Healthcare Life Sciences/Cytiva, VWR International B.V., Amsterdam, The Netherlands; 2. Bio-Rad Laboratories B.V., Veenendaal, The Netherlands.

\subsection{Conclusions}

Traditional enzyme purification procedures, whereby different chromatographic steps are required in order to obtain a pure protein, have played an eminent role in the development of the biocatalysis field. Nowadays, these methods have been replaced for the most part by affinity chromatographic techniques in which recombinant proteins fused with a specific tag can be effectively purified in a single step. Regarding the latter, it should be kept in mind that in many cases, an additional polishing step is required to remove critical impurities.

In this review, we have summarized our longstanding experience with the purification and characterization of redox enzymes. Purification procedures for these proteins do not significantly differ from the purification methods used for, e.g., hydrolases or transferases. However, with redox enzymes, and, in general, with proteins containing cofactors, potential cofactor dissociation during purification steps should be taken into account. Thus, addition of excess cofactor during purification can be essential for keeping the enzyme stable and active. We show that conventional chromatographic purification techniques can also be used for the large-scale preparation of apoproteins and for gaining insights into the molecular and hydrodynamic properties of the enzymes. Combining the specific 
opportunities of the different chromatographic techniques with the still growing DNA-recombinant toolbox will make it possible in the future to identify and purify new exciting biocatalysts.

\section{References}

1 Kohls, H., Steffen-Munsberg, F., and Höhne, M. (2014). Recent achievements in developing the biocatalytic toolbox for chiral amine synthesis. Curr. Opin. Chem. Biol. 19: 180-192.

2 Zmijewski, M. (2000). Stereoselective biocatalysis. New York: American Chemical Society.

3 Faber, K. (2018). Biotransformations in organic chemistry, 1-434. Heidelberg: Springer-Verlag.

4 Sheldon, R.A. and Brady, D. (2018). The limits to biocatalysis: pushing the envelope. Chem. Commun. 54: 6088-6104.

5 Woodley, J.M. (2019). Reaction engineering for the industrial implementation of biocatalysis. Top. Catal. 62: 1202-1207.

6 de Souza, P.M. and de Oliveira Magalhães, P. (2010). Application of microbial $\alpha$-amylase in industry: a review. Braz. J. Microbiol. 41 (4): 850-861.

7 Bornscheuer, U.T. and Kazlauskas, R.J. (2006). Hydrolases in organic synthesis: regio- and stereoselective biotransformations, 1-355. Weinheim: Wiley-VCH Verlag GmbH and Co. KGaA.

8 Filho, D.G., Silva, A.G., and Guidini, C.Z. (2019). Lipases: sources, immobilization methods, and industrial applications. Appl. Microbiol. Biotechnol. 103 (18): 7399-7423.

9 Bornscheuer, U.T., Huisman, G.W., Kazlauskas, R.J. et al. (2012). Engineering the third wave of biocatalysis. Nature 485 (7397): 185-194.

10 Burgess, R.R. and Deutscher, M.P. (eds.) (2009). Guide to Protein Purification. Methods in Enzymology 463 San Diego: Academic Press.

11 Rhodes, D.G. and Laue, T.M. (2009). Determination of protein purity. In: Methods in Enzymology (eds. R.R. Burgess and M.P. Deutscher), 463: 677-689. San Diego: Academic Press.

12 Burgess, R.R. (2009). Protein precipitation techniques. In: Methods in Enzymology (eds.

R.R. Burgess and M.P. Deutscher), 463: 331-342. San Diego: Academic Press.

13 de Jong, E., van Berkel, W.J.H., van der Zwan, R.P. et al. (1992). Purification and characterization of vanillyl-alcohol oxidase from Penicillium simplicissimum. Eur. J. Biochem. 208 (3): 651-657.

14 Fraaije, M.W., Roubroeks, H.P., Hagen, W.R. et al. (1996). Purification and characterization of an intracellular catalase-peroxidase from Penicillium simplicissimum. Eur. J. Biochem. 235: 192-198.

15 Jadan, A.P., van Berkel, W.J.H., Golovleva, L.A. et al. (2001). Purification and properties of $p$-hydroxybenzoate hydroxylases from Rhodococcus strains. Biochem. Mosc. 66 (8): 898-903.

16 Moonen, M.J.H., Kamerbeek, N.M., Westphal, A.H. et al. (2008). Elucidation of the 4-hydroxyacetophenone catabolic pathway in Pseudomonas fluorescens ACB. J. Bacteriol. 190 (15): 5190-5198. 
17 Eppink, M.H.M., Schreuder, H.A., and van Berkel, W.J.H. (1998). Interdomain binding of NADPH in $p$-hydroxybenzoate hydroxylase as suggested by kinetic, crystallographic and modeling studies of histidine 162 and arginine 269 variants. J. Biol. Chem. 273 (33): 21031-21039.

18 Jungbauer, A. and Hahn, R. (2009). Ion-exchange chromatography. In: Methods in Enzymology (eds. R.R. Burgess and M.P. Deutscher), 463: 349-371. San Diego: Academic Press.

19 Müller, F., Voordouw, G., van Berkel, W.J.H. et al. (1979). A study of p-hydroxybenzoate hydroxylase from Pseudomonas fluorescens. Eur. J. Biochem. 101 (1): 235-244.

20 Seibold, B., Matthes, M., Eppink, M.H.M. et al. (1996). 4-Hydroxybenzoate hydroxylase from Pseudomonas sp. CBS3. Purification, characterization, gene cloning, sequence analysis and assignment of structural features determining the coenzyme specificity. Eur. J. Biochem. 239 (2): 469-478.

21 van Berkel, W.J.H. and Müller, F. (1987). The elucidation of the microheterogeneity of highly purified $p$-hydroxybenzoate hydroxylase from Pseudomonas fluorescens by various biochemical techniques. Eur. J. Biochem. 167 (1): 35-46.

22 van Berkel, W.J.H., Westphal, A.H., Eschrich, K. et al. (1992). Substitution of Arg214 at the substrate binding site of $p$-hydroxybenzoate hydroxylase from Pseudomonas fluorescens. Eur. J. Biochem. 210 (2): 411-419.

23 van Berkel, W.J.H. and van den Tweel, W.J.J. (1991). Purification and characteriation of 3-hydroxyphenylacetate 6-hydroxylase: a novel FAD-dependent monooxygenase from a Flavobacterium species. Eur. J. Biochem. 201 (3): 585-592.

24 Eppink, M.H.M., Cammaart, E., van Wassenaar, D. et al. (2000). Purification and properties of hydroquinone hydroxylase, a FAD-dependent monooxygenase involved in the catabolism of 4-hydroxybenzoate in Candida parapsilosis CBS604. Eur. J. Biochem. 267 (23): 6832-6840.

25 Kirchner, U., Westphal, A.H., Müller, R. et al. (2003). Phenol hydroxylase from Bacillus thermoglucosidasius A7, a two-protein component monooxygenase with a dual role for FAD. J. Biol. Chem. 278 (48): 47545-47553.

26 Montersino, S. and van Berkel, W.J.H. (2012). Functional annotation and characterization of 3-hydroxybenzoate 6-hydroxylase from Rhodococcus jostii RHA1. Biochim. Biophys. Acta 1824 (3): 433-442.

27 Kamerbeek, N.M., Moonen, M.J.H., van der Ven, J.G.M. et al. (2001). 4-Hydroxyacetophenone monooxygenase from Pseudomonas fluorescens ACB. Eur. J. Biochem. 268 (9): 2547-2557.

28 Kuijpers, T.F.M., van Herk, T., Vincken, J.-P. et al. (2014). Potato and mushroom polyphenol oxidase activities are differently modulated by natural plant extracts. J. Agric. Food Chem. 62 (1): 214-221.

29 Frommhagen, M., Sforza, S., Westphal, A.H. et al. (2015). Discovery of the combined oxidative cleavage of plant xylan and cellulose by a new fungal polysaccharide monooxygenase. Biotechnol. Biofuels 8 (101): 12.

30 Ewing, T.A., Gygli, G., and van Berkel, W.J.H. (2016). A single loop is essential for the octamerization of vanillyl-alcohol oxidase. FEBS J. 283 (13): 2546-2559.

31 Tamayo-Ramos, J.A., van Berkel, W.J.H., and de Graaff, L.H. (2012). Biocatalytic potential of laccase-like multicopper oxidases from Aspergillus niger. Microb. Cell Factories 11: 165. 
32 Ferraroni, M., Westphal, A.H., Borsari, M. et al. (2017). Structure and function of Aspergillus niger laccase McoG. Biocatalysis 3 (1): 10.

33 Moonen, M.J.H., Synowsky, S.A., van den Berg, W.A.M. et al. (2008). Hydroquinone dioxygenase from Pseudomonas fluorescens ACB: a novel member of the family of nonheme-iron(II)-dependent dioxygenases. J. Bacteriol. 190 (15): 5199-5209.

34 Dicko, M.H., Gruppen, H., Hilhorst, R. et al. (2006). Biochemical characterization of the major sorghum grain peroxidase. FEBS J. 273 (10): 2293-2307.

35 Weber, F.J., van Berkel, W.J.H., Hartmans, S. et al. (1992). Purification and properties of the NADH reductase component of alkene monooxygenase from Mycobacterium strain E3.

J. Bacteriol. 174 (10): 3275-3281.

36 van Iersel, M.F., Eppink, M.H.M., van Berkel, W.J.H. et al. (1997). Purification and characterization of a novel NADP-dependent branched-chain alcohol dehydrogenase from Saccharomyces cerevisiae. Appl. Environ. Microbiol. 63 (10): 4079-4082.

37 van der Werf, M.J., van der Ven, C., Barbirato, F. et al. (1999). Stereoselective carveol dehydrogenase from Rhodococcus erythropolis DCL14: A novel nicotinoprotein belonging to the short chain dehydrogenase/reductase superfamily. J. Biol. Chem. 274 (37): 26296-26304.

38 Leferink, N.G.H., Heuts, D.P.H.M., Fraaije, M.W. et al. (2008). The growing VAO flavoprotein family. Arch. Biochem. Biophys. 474 (2): 292-301.

39 Kudryashova, E.V., Leferink, N.G.H., Slot, I.G.M. et al. (2011). Galactonolactone oxidoreductase from Trypanosoma cruzi employs a FAD cofactor for the synthesis of vitamin C. Biochim. Biophys. Acta 1814 (5): 545-552.

40 Huijbers, M.M.E. and van Berkel, W.J.H. (2015). High yields of active Thermus thermophilus proline dehydrogenase are obtained using maltose-binding protein as a solubility tag. Biotechnol. J. 10 (3): 395-403.

41 Stellwagen, E. (2009). Gel filtration. In: Methods in Enzymology (eds. R.R. Burgess and M.P. Deutscher), 463: 373-385. San Diego: Academic Press.

42 Westphal, A.H., Geerke-Volmer, A.A., van Mierlo, C.P.M. et al. (2017). Chaotropic heat treatment resolves native-like aggregation of a heterologously produced hyperthermostable laminarinase. Biotechnol. J. 12 (6): 11.

43 Rhodes, D.G., Bossio, R.E., and Laue, T.M. (2009). Determination of size, molecular weight, and presence of subunits. In: Methods in Enzymology (eds. R.R. Burgess and M.P. Deutscher), 463: 691-723. San Diego: Academic Press.

44 Müller, F. and van Berkel, W.J.H. (1982). A study on p-hydroxybenzoate hydroxylase from Pseudomonas fluorescens. Eur. J. Biochem. 128 (1): 21-27.

45 van Berkel, W.J.H., Benen, J.A.E., and Snoek, M.C. (1991). On the FAD-induced dimerization of apo-lipoamide dehydrogenase from Azotobacter vinelandii and Pseudomonas fluorescens. Eur. J. Biochem. 197 (3): 769-779.

46 Fraaije, M.W., van den Heuvel, R.H.H., van Berkel, W.J.H. et al. (1999). Covalent flavinylation is essential for efficient redox catalysis in vanillyl-alcohol oxidase. J. Biol. Chem. 274 (50): 35514-35520.

47 Tahallah, N., van den Heuvel, R.H.H., van den Berg, W.A.M. et al. (2002). Cofactor-dependent assembly of the flavoenzyme vanillyl-alcohol oxidase. J. Biol. Chem. 277 (39): 36425-36432.

48 Fraaije, M.W., Mattevi, A., and van Berkel, W.J.H. (1997). Mercuration of vanillyl-alcohol oxidase from Penicillium simplicissimum generates inactive dimers. FEBS Lett. 402: 33-35. 
49 van Berkel, W.J.H., van den Heuvel, R.H.H., Versluis, C. et al. (2000). Detection of intact megaDalton protein assemblies of vanillyl-alcohol oxidase by mass spectrometry. Protein Sci. 9 (3): 435-439.

50 Huijbers, M.M.E., van Alen, I., Wu, J.W. et al. (2018). Functional impact of the N-terminal arm of proline dehydrogenase from Thermus thermophilus. Molecules 23 (1): 184.

51 Huijbers, M.M.E., Wu, J.W., Westphal, A.H. et al. (2019). Dimerization of proline dehydrogenase from Thermus thermophilus is crucial for its thermostability. Biotechnol. J. 14 (5): 1800540.

52 Urh, M., Simpson, D., and Zhao, K. (2009). Affinity chromatography: general methods. In: Methods in Enzymology (eds. R.R. Burgess and M.P. Deutscher), 463: 417-438. San Diego: Academic Press.

53 Vos, R.M.E., Snoek, M.C., van Berkel, W.J.H. et al. (1988). Differential induction of rat hepatic glutathione S-transferase isoenzymes by hexachlorobenzene and benzyl isothiocyanate: comparison with induction by phenobarbital and 3-methylcholanthrene. Biochem. Pharmacol. 37 (6): 1077-1082.

54 Williams, R.E. and Bruce, N.C. (2002). New uses for an old enzyme: the old yellow enzyme family of flavoenzymes. Microbiology 148 (6): 1607-1614.

55 Scholtissek, A., Tischler, D., Westphal, A.H. et al. (2017). Old yellow enzyme-catalysed asymmetric hydrogenation: linking family roots with improved catalysis. Catalysts 7 (5): 130.

56 Abramovitz, A.S. and Massey, V. (1976). Purification of intact old yellow enzyme using an affinity matrix for the sole chromatographic step. J. Biol. Chem. 251 (17): 5321-5326.

57 Eweg, J.K., Müller, F., and van Berkel, W.J.H. (1982). On the enigma of old yellow enzyme's spectral properties. Eur. J. Biochem. 129 (2): 303-316.

58 Stott, K., Saito, K., Thiele, D.J. et al. (1993). Old yellow enzyme. The discovery of multiple isozymes and a family of related proteins. J. Biol. Chem. 268 (9): 6097-6106.

59 McCue, J.T. (2009). Theory and use of hydrophobic interaction chromatography in protein purification applications. In: Methods in Enzymology (eds. R.R. Burgess and M.P. Deutscher), 463: 405-414. San Diego: Academic Press.

60 Benen, J.A.E., Sánchez-Torres, P., Wagemaker, M.J.M. et al. (1998). Molecular cloning, sequencing, and heterologous expression of the vaoA gene from Penicillium simplicissimum CBS 170.90 encoding vanillyl-alcohol oxidase. J. Biol. Chem. 273 (14): 7865-7872.

61 Eppink, M.H.M., Boeren, S.A., Vervoort, J.M. et al. (1997). Purification and properties of 4-hydroxybenzoate 1-hydroxylase (decarboxylating), a novel flavin adenine dinucleotidedependent monooxygenase from Candida parapsilosis CBS604. J. Bacteriol. 179 (21): 6680-6687.

62 Westphal, A.H. and de Kok, A. (1988). Lipoamide dehydrogenase from Azotobacter vinelandii. Molecular cloning, organization and sequence analysis of the gene. Eur. J. Biochem. 172 (2): 299-305.

63 Benen, J.A.E., van Berkel, W.J.H., van Dongen, W.M.A.M. et al. (1989). Molecular cloning and sequence determination of the lpd gene encoding lipoamide dehydrogenase from Pseudomonas fluorescens. Microbiology 135 (7): 1787-1797.

64 van Berkel, W.J.H., van den Berg, W.A.M., and Müller, F. (1988). Large-scale preparation and reconstitution of apo-flavoproteins with special reference to butyryl-CoA dehydrogenase from Megasphaera elsdenii. Eur. J. Biochem. 178 (1): 197-207. 
65 Hefti, M.H., Vervoort, J.M., and van Berkel, W.J.H. (2003). Deflavination and reconstitution of flavoproteins: Tackling fold and function. Eur. J. Biochem. 270 (21): 4227-4242.

66 Cummings, L.J., Snyder, M.A., and Brisack, K. (2009). Protein chromatography on hydroxyapatite columns. In: Methods in Enzymology (eds. R.R. Burgess and M.P. Deutscher), 463: 387-404. San Diego: Academic Press.

67 Brondyk, W.H. (2009). Selecting an appropriate method for expressing a recombinant protein. In: Methods in Enzymology (eds. R.R. Burgess and M.P. Deutscher), 463: 131-147. San Diego: Academic Press.

68 Zerbs, S., Frank, A.M., and Collart, F.R. (2009). Bacterial systems for production of heterologous proteins. In: Methods in Enzymology (eds. R.R. Burgess and M.P. Deutscher), 463: 149-168. San Diego: Academic Press.

69 Cregg, J.M., Tolstorukov, I., Kusari, A. et al. (2009). Expression in the yeast Pichia pastoris. In: Methods in Enzymology (eds. R.R. Burgess and M.P. Deutscher), 463: 169-189. San Diego: Academic Press.

70 Malhotra, A. (2009). Tagging for protein expression. In: Methods in Enzymology (eds. R.R. Burgess and M.P. Deutscher), 463: 239-258. San Diego: Academic Press.

71 Block, H., Maertens, B., Spriestersbach, A. et al. (2009). Immobilized-metal affinity chromatography (IMAC): a review. In: Methods in Enzymology (eds. R.R. Burgess and M.P. Deutscher), 463: 439-473. San Diego: Academic Press.

72 Leferink, N.G.H., van den Berg, W.A.M., and van Berkel, W.J.H. (2008). L-Galactono$\gamma$-lactone dehydrogenase from Arabidopsis thaliana, a flavoprotein involved in vitamin C biosynthesis. FEBS J. 275 (4): 713-726.

73 Tischler, D., Eulberg, D., Lakner, S. et al. (2009). Identification of a novel self-sufficient styrene monooxygenase from Rhodococcus opacus 1CP. J. Bacteriol. 191 (15): 4996.

74 Riedel, A., Heine, T., Westphal, A.H. et al. (2015). Catalytic and hydrodynamic properties of styrene monooxygenases from Rhodococcus opacus 1CP are modulated by cofactor binding. AMB Express 5 (1): 112.

75 Montersino, S., te Poele, E., Orru, R. et al. (2017). 3-Hydroxybenzoate 6-hydroxylase from Rhodococcus jostii RHA1 contains a phosphatidylinositol cofactor. Front. Microbiol. 8 (1110): 11.

76 Riedel, A., Mehnert, M., Paul, C.E. et al. (2015). Functional characterization and stability improvement of a 'thermophilic-like' ene-reductase from Rhodococcus opacus 1CP. Front. Microbiol. 6: 1073.

77 Mendes, S., Banha, C., Madeira, J. et al. (2016). Characterization of a bacterial pyranose 2-oxidase from Arthrobacter siccitolerans. J. Mol. Catal. B 133: S34-S43.

78 Heine, T., Scholtissek, A., Westphal, A.H. et al. (2017). N-terminus determines activity and specificity of styrene monooxygenase reductases. Biochim. Biophys. Acta 1865 (12): 1770-1780.

79 Ewing, T.A., van Noord, A., Paul, C.E. et al. (2018). A xylenol orange-based screening assay for the substrate specificity of flavin-dependent para-phenol oxidases. Molecules 23 (164): 18.

80 Nguyen, Q.T., de Gonzalo, G., Binda, C. et al. (2016). Biocatalytic properties and structural analysis of eugenol oxidase from Rhodococcus jostii RHA1: a versatile oxidative biocatalyst. ChemBioChem 17 (14): 1359-1366. 
81 Dijkman, W.P. and Fraaije, M.W. (2014). Discovery and characterization of a 5-hydroxymethylfurfural oxidase from Methylovorus sp. strain MP688. Appl. Environ. Microbiol. 80 (3): 1082.

82 Ewing, T.A., Dijkman, W.P., Vervoort, J.M. et al. (2014). The oxidation of thiols by flavoprotein oxidases: a biocatalytic route to reactive thiocarbonyls. Angew. Chem. Int. Ed. 53 (48): 13206-13209.

83 Westphal, A.H., Tischler, D., Heinke, F. et al. (2018). Pyridine nucleotide coenzyme specificity of $p$-hydroxybenzoate hydroxylase and related flavoprotein monooxygenases. Front. Microbiol. 9 (3050): 10.

84 Schlager, B., Straessle, A., and Hafen, E. (2012). Use of anionic denaturing detergents to purify insoluble proteins after overexpression. BMC Biotechnol. 12: 95.

85 Ruiz-Dueñas, F.J., Ferreira, P., Martínez, M.J. et al. (2006). In vitro activation, purification, and characterization of Escherichia coli expressed aryl-alcohol oxidase, a unique $\mathrm{H}_{2} \mathrm{O}_{2}$ producing enzyme. Protein Expr. Purif. 45 (1): 191-199.

86 Fürst, M.J.L.J., Kerschbaumer, B., Rinnofner, C. et al. (2019). Exploring the biocatalytic potential of a self-sufficient cytochrome P450 from Thermothelomyces thermophila. Adv. Synth. Catal. 361 (11): 2487-2496.

87 Fürst, M.J.L.J., Martin, C., Lončar, N. et al. (2018). Experimental protocols for generating focused mutant libraries and screening for thermostable proteins. In: Methods in Enzymology (ed. N. Scrutton), 608: 151-187. San Diego: Academic Press.

88 Fürst, M.J.L.J., Boonstra, M., Bandstra, S. et al. (2019). Stabilization of cyclohexanone monooxygenase by computational and experimental library design. Biotechnol. Bioeng. 116 (9): 2167-2177.

89 Hefti, M.H., Milder, F.J., Boeren, S.A. et al. (2003). A His-tag based immobilization method for the preparation and reconstitution of apoflavoproteins. Biochim. Biophys. Acta 1619 (2): 139-143.

$90 \mathrm{Xu}$, L., Zhang, D., Mu, W. et al. (2006). Reversible resolution of flavin and pterin cofactors of His-tagged Escherichia coli DNA photolyase. Biochim. Biophys. Acta 1764 (9): 1454-1461.

91 Li, G., Fürst, M.J.L.J., Mansouri, H.R. et al. (2017). Manipulating the stereoselectivity of the thermostable Baeyer-Villiger monooxygenase TmCHMO by directed evolution. Org. Biomol. Chem. 15 (46): 9824-9829.

92 Li, G., Garcia-Borràs, M., Fürst, M.J.L.J. et al. (2018). Overriding traditional electronic effects in biocatalytic Baeyer-Villiger reactions by directed evolution. J. Am. Chem. Soc. 140 (33): 10464-10472.

93 Fürst, M.J.L.J., Romero, E., Gómez Castellanos, J.R. et al. (2018). Side-chain pruning has limited impact on substrate preference in a promiscuous enzyme. ACS Catal. 8 (12): 11648-11656.

94 Fürst, M.J.L.J., Savino, S., Dudek, H.M. et al. (2017). Polycyclic ketone monooxygenase from the thermophilic fungus Thermothelomyces thermophila: a structurally distinct biocatalyst for bulky substrates. J. Am. Chem. Soc. 139 (2): 627-630.

95 Heuts, D.P.H.M., van Hellemond, E.W., Janssen, D.B. et al. (2007). Discovery, characterization, and kinetic analysis of an alditol oxidase from Streptomyces coelicolor. J. Biol. Chem. 282 (28): 20283-20291. 
96 Huijbers, M.M.E. and van Berkel, W.J.H. (2016). A more polar N-terminal helix releases MBP-tagged Thermus thermophilus proline dehydrogenase from tetramer-polymer self-association. J. Mol. Catal. B 134: 340-346.

97 Huijbers, M.M.E., Martínez-Júlvez, M., Westphal, A.H. et al. (2017). Proline dehydrogenase from Thermus thermophilus does not discriminate between FAD and FMN as cofactor. Sci. Rep. 7: 43880. 
